\title{
Validity of the association between periodontitis and female infertility conditions: a concise review
}

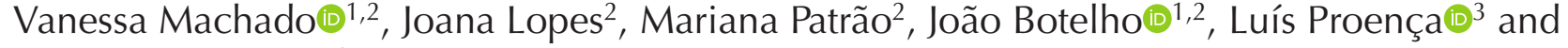 \\ José João Mendes (iD) ${ }^{2}$ \\ ${ }^{1}$ Periodontology Department, Centro de Investigação Interdisciplinar Egas Moniz (CiiEM), Egas Moniz, CRL, Monte \\ de Caparica, Portugal, ${ }^{2}$ Clinical Research Unit (CRU), CiiEM, Egas Moniz, CRL, Monte de Caparica, Portugal and \\ ${ }^{3}$ Quantitative Methods for Health Research Unit (MQIS), CiiEM, Egas Moniz, CRL, Monte de Caparica, Portugal \\ Correspondence should be addressed to V Machado; Email: vmachado@egasmoniz.edu.pt
}

\begin{abstract}
Hormones and inflammatory mechanisms are implicated with female reproductive function, including follicle maturation, ovulation, embryo implantation, and pregnancy. Periodontitis is a chronic inflammatory disease due to a polymicrobial disruption of the homeostasis and may be considered as a potential risk factor that affect female fertility. The role of periodontitis is becoming meaningful, with significant associations with polycystic ovary syndrome, endometriosis and bacterial vaginosis. Further, periodontitis is linked with known risk factors towards female infertility, such as age, obesity, and chronic kidney disease. This review aims to summarize the available evidence on the association between periodontitis and female infertility-associated conditions, and to discuss warranting steps in future research.

Reproduction (2020) 160 R41-R54
\end{abstract}

\section{Introduction}

According to the International Committee for Monitoring Assisted Reproductive Technology (ICMART) and the World Health Organization (WHO), infertility is defined as a condition where the reproductive system is incapable to secure a clinical pregnancy after 12 months or more of regular unprotected sexual intercourse (Adamson et al. 2018). Moreover, a healthy woman at the time of conception is more likely to have a successful pregnancy and to deliver a healthy child (Stephenson et al. 2018).

In 2010, 48.5 million couples worldwide were estimated to be infertile (Mascarenhas et al. 2012), yet nowadays, infertility is anticipated to be increasing, affecting more than 186 million people $(8-12 \%$ of reproductive-aged couples), and fluctuates according to the level of development of the country. Furthermore, 14.3 and $25 \%$ of the couples are affected in the Western world and in developing countries, respectively (Vander Borght \& Wyns 2018).

The consequences of infertility may hamper population growth (Vander Borght \& Wyns 2018) and could negatively impact on the marital relationship (Onat \& Beji 2012), sexual satisfaction (Ramezanzadeh et al. 2006) and psychosocial well-being (Cousineau \& Domar 2007). Besides, couples can also experience anger, sadness, anxiety, depression, guilt, shame, a feeling of loss of control and incompleteness, dysfunction coping strategies, altered self-esteem, social isolation and increased marital distress (Cousineau \& Domar 2007, Schmidt 2009, Omu \& Omu 2010, Péloquin et al. 2013).

Infertility is a multi-factorial and multi-faceted clinical condition for both members of a couple and can be categorized as primary or secondary. In females, primary infertility represents a woman that has never been diagnosed with a clinical pregnancy and meets the infertility criteria. Secondary female infertility refers to the inability to become pregnant or to carry a baby to term after a previous successful pregnancy (ZegersHochschild et al. 2017). Aging is a key negative factor for women fertility (Hart 2016), though other risk factors comprising lifestyle and environmental factors have been gaining some relevance (Vander Borght \& Wyns 2018).

Among the relevant factors for female infertility, oral health is key for maintaining and allowing vital quotidian functions. A recent review highlighted the urgent need to address oral diseases as a global health priority (Peres et al. 2019). In particular, oral diseases share common risk factors with several conditions and have recognized impactfulness, such as pain, reduced quality of life, family interference, loss of work productivity and required high costs for treatment (Peres et al. 2019). One of the most important group of oral conditions is periodontal disease which affect the periodontium.

The periodontium encompasses mineralized (alveolar bone proper and root cementum) and soft connective 
tissues (periodontal ligament and gingiva) (Mark Bartold \& Van Dyke 2013). Periodontal health is defined as an absence or very significant reduction of clinical signs of periodontal inflammation (Lang \& Bartold 2018). Periodontal disease initially presents as gingivitis, a reversible inflammation of the periodontium's soft tissues, with gingival bleeding and swelling. If progresses, gingivitis might evolve to periodontitis (PD), which is a progressive destruction of the periodontium.

The pathogenesis of PD relies on a complex interdependent relationship between a dysbiotic biofilm and host response, and if untreated results in the loss of periodontal attachment (Meyle \& Chapple 2015, Roberts \& Darveau 2015, Tonetti et al. 2018). The symptoms start with reversible gum inflammation (Bartold \& Van Dyke 2017, Murakami et al. 2018, Trombelli et al. 2018) to an exacerbated and uncontrolled inflammatory response from the innate and adaptive immune systems (Ebersole et al. 2013, 2017). Ahead, periodontal tissues are progressively destroyed in an irreversible fashion, causing tooth mobility and its loss (Darveau 2010, Tonetti et al. 2015, 2018, Kinane et al. 2017) (Fig. 1).

The systemic repercussions caused by PD are now well established, and occur when bacteria and their products pass through the gingival epithelial barrier, and then spread into the bloodstream causing infectious and inflammatory responses (Chan et al. 2017, Albandar et al. 2018) (Fig. 1).

The main cause of PD, that is biofilm accumulation, results from negligent oral hygiene habits. Smoking habits are a key risk factor for periodontal disease Jansson \& Lavstedt 2002, Johannsen et al. 2014, Buduneli \& Scott 2018), though due to the common inflammatory pathways, PD is strongly associated with other clinical conditions including diabetes mellitus (DM), metabolic syndrome, high blood pressure, rheumatoid arthritis, cardiovascular disease, stress, among others (Preshaw et al. 2012, D'Aiuto et al. 2013, Nibali et al. 2013, Tonetti \& Van Dyke 2013, Jepsen et al. 2018, Polak \& Shapira 2018, Botelho et al. 2020a, Hussain et al. 2020, Machado et al. 2020a,b). Also, PD has significant impact on the quality of life yet it can be recovered after periodontal treatment (Buset et al. 2016, Botelho et al. 2020b).

Very recently, two systematic reviews have comprehensively linked PD with male infertility and erectile dysfunction (Práger et al. 2017, Kellesarian et al. 2018a,b). PD was found highly prevalent among infertile men and severe PD was associated with higher deterioration of sperm quality (Zhu et al. 2010). Moreover, men with PD are at increased risk of developing erectile dysfunction, oligozoospermia and concomitant asthenozoospermia than periodontally healthy individuals (Kellesarian etal. 2017, 2018b, Práger et al. 2017). Drawing parallels with male infertility, the association between PD and female infertility-related conditions is important to discuss, and a comprehensive revision would be of great interest.

Notwithstanding, an important question that still remains is whether female fertility may influence the onset and progression of PD and if periodontal infection and consequent inflammatory burden may influence female infertility (Kassebaum et al. 2014). Thus, this review aims to summarize the available lines of evidence on the relation between PD and female infertility-associated conditions, as well the possible pathophysiological pathways.

\section{Female infertility-related conditions and Periodontitis}

PD produces a local (saliva and gingival crevicular fluid (GCF)) and systemic inflammatory response (Kjeldsen et al. 1993, Cekici et al. 2014, Barros et al. 2016, Stadler et al. 2016, Cardoso et al. 2018, Polak \& Shapira 2018). This response triggers the production of cytokines, resulting in tissue destruction, immunological reactions and indirectly influences other systems (Garlet 2010, Gonzales 2015). Comprehensively, the association between the periodontal status and the female reproductive system seems difficult to follow. Notwithstanding, the secondary role of PD in other diseases might contribute to explain how it can compromise female fertility. PD has been linked to polycystic ovary syndrome (PCOS), endometriosis (EM), obesity, bacterial vaginosis (BV), chronic kidney disease $(C K D)$, and age, which in turn are risk factors affecting the spontaneous probability of conception.

\section{Polycystic ovary syndrome}

PCOS is a genetically complex endocrine, reproductive and metabolic disorder, affecting $5-15 \%$ of women in reproductive age worldwide (Azziz 2016). It is characterized by hyperandrogenism with distorted gonadotropin secretory activity, hyperinsulinemia, hypothalamic-pituitary-ovarian (HPO) axis dysfunction, ovulatory and menstrual dysfunction, and the presence of polycystic ovaries (Hull 1987, Norman et al. 2007, Dumesic et al. 2015, McCartney and Marshall 2016, Lambertini et al. 2017, Macut et al. 2017, Greenwood \& Huddleston 2019). Moreover, PCOS appears to be associated with increased metabolic syndrome (MetS), including type $2 \mathrm{DM}$ and insulin resistance (Dunaif 1997, Macut et al. 2017, Greenwood \& Huddleston 2019), dyslipidemia (Caserta et al. 2014, Mirza et al. 2014), cardiovascular disease (Osibogun et al. 2019), and nonalcoholic fatty liver disease (Paschou et al. 2020). Despite many theories, the etiology of this syndrome remains poorly understood. 


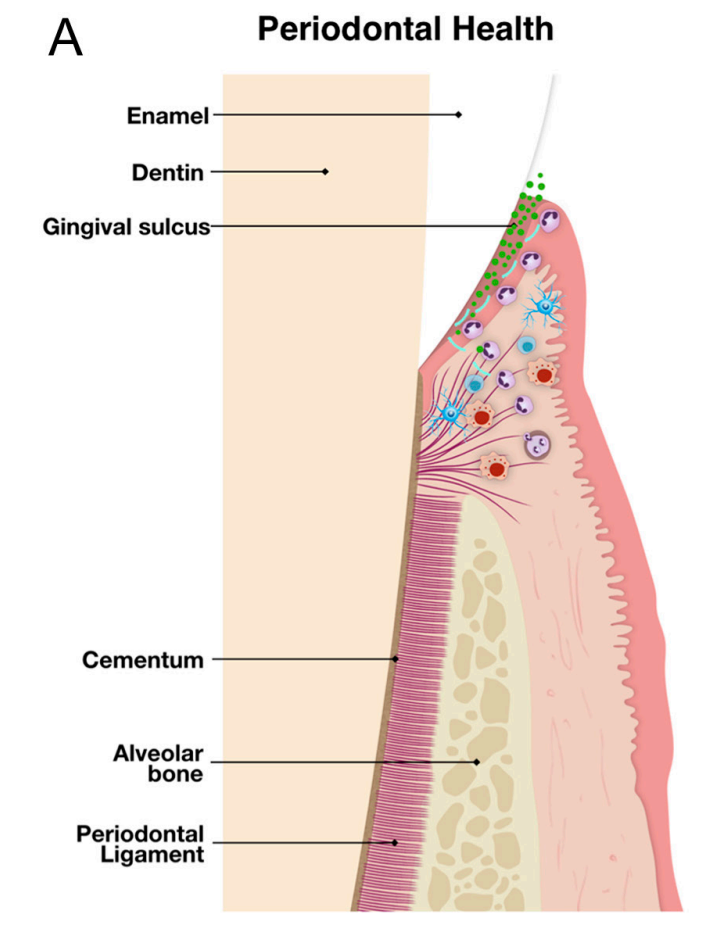

B

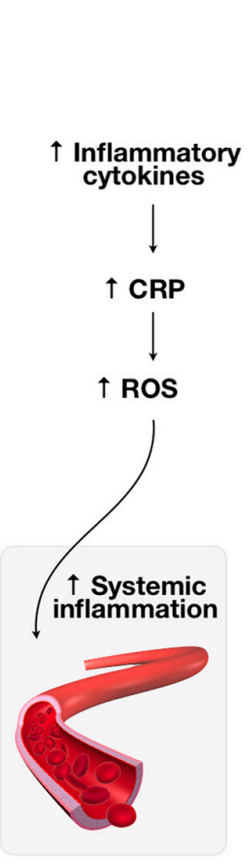

Periodontitis

Figure 1 Periodontal health and immune response in periodontitis. Schematics of healthy gingiva (A) and periodontitis (B). The oral microbiome is a complex form ecosystems and contribute to maintain health when the the interaction between host and pathogen is in equilibrium in the gingival sulcus and periodontal pocket site. In this healthy environment, the host have a protective response by the immunity system and commensal bacteria. The first line of the defense is the sentinel cells involving macrophages, dendritic cells and mast cells, securing for evidence of pathogen invaders (A). However, when the biofilm-host balance is lost, causing a dysbiosis and immune overreaction of the host to microbial presences. This imbalance depends on the variance of patient's genetic, immune and biofilm profiles, and results in a heightened inflammatory state with increased levels of cytokines that leads to the local resorption of alveolar bone by osteoclast. These inflammatory cytokines activate macrophages, neutrophils, and fibroblasts to generate reactive oxygen species (ROS), which ultimately results in tissue damage.

Growing evidence supports a relationship between PCOS and chronic infections through the increase of oxidative stress (OS), inflammatory burden, adhesion molecules and leukocyte response (Pawelczak et al. 2014, Porwal et al. 2014, Dos Santos et al. 2015, Victor et al. 2016, Saglam et al. 2017a) (Fig. 2). Accordingly, the relationship between PCOS and PD was initially based on its common association with MetS (Dursun et al. 2011). In the latter, PCOS women had higher levels of periodontal inflammation and destruction than non-PCOS females, with marked hallmarks of OS and glycemic dysregulation on GCF (Dursun et al. 2011). Indeed, DM and OS are well-established risk factors towards PD (Preshaw et al. 2012, Chen et al. 2019) and might be significant mediating factors in the PCOS-PD way. Additionally, MetS may play a key role by inducing systemic inflammation and insulin resistance (Nibali et al. 2013).

Later, the cascade of proinflammatory events was proposed as a possible interplay between PD and PCOS (Özçaka et al. 2012, 2013, Akcall et al. 2015, Akcalı et al. 2017, Kellesarian et al. 2017, Tong et al. 2019). Both diseases appear to act in a synergistic manner to increase the expression of proinflammatory cytokines
(Knebel et al. 2008, Özçaka et al. 2013), and the severity of PD might also be associated with the aggravation of PCOS (Porwal et al. 2014).

Comprehensively, the possible mechanism linking PD and PCOS is rooted in the chronic subclinical inflammation of both diseases (Escobar-Morreale et al. 2011, Tong et al. 2019). In other words, a chronic subclinical inflammatory status elevates the concentrations of proinflammatory markers (such as C-Reactive Protein (CRP), tumor necrosis factor- $\alpha$ (TNF- $\alpha$ ), interleukin (IL)-6, IL-17, and matrix metalloproteinase-9) (Özçaka et al. 2012, 2013, Akcali et al. 2013, Cekici et al. 2014) and potentiates an oxidative stress environment (through local oxidant status-like myeloperoxidase and nitric oxide) (Dursun et al. 2011, Akcalı et al. 2017). Consequently, the subclinical inflammation due to PCOS may worsen periodontal destruction, and in the opposite way, subclinical inflammation due to PD through direct invasion of periodontal microbiota might underpin the pathogenesis of PCOS. Additionally, PD management has been implicated in insulin levels control as periodontal treatment alleviated high glycemic levels (D'Aiuto et al. 2018), and therefore, uncontrolled PD may indirectly impact on PCOS clinical status. 


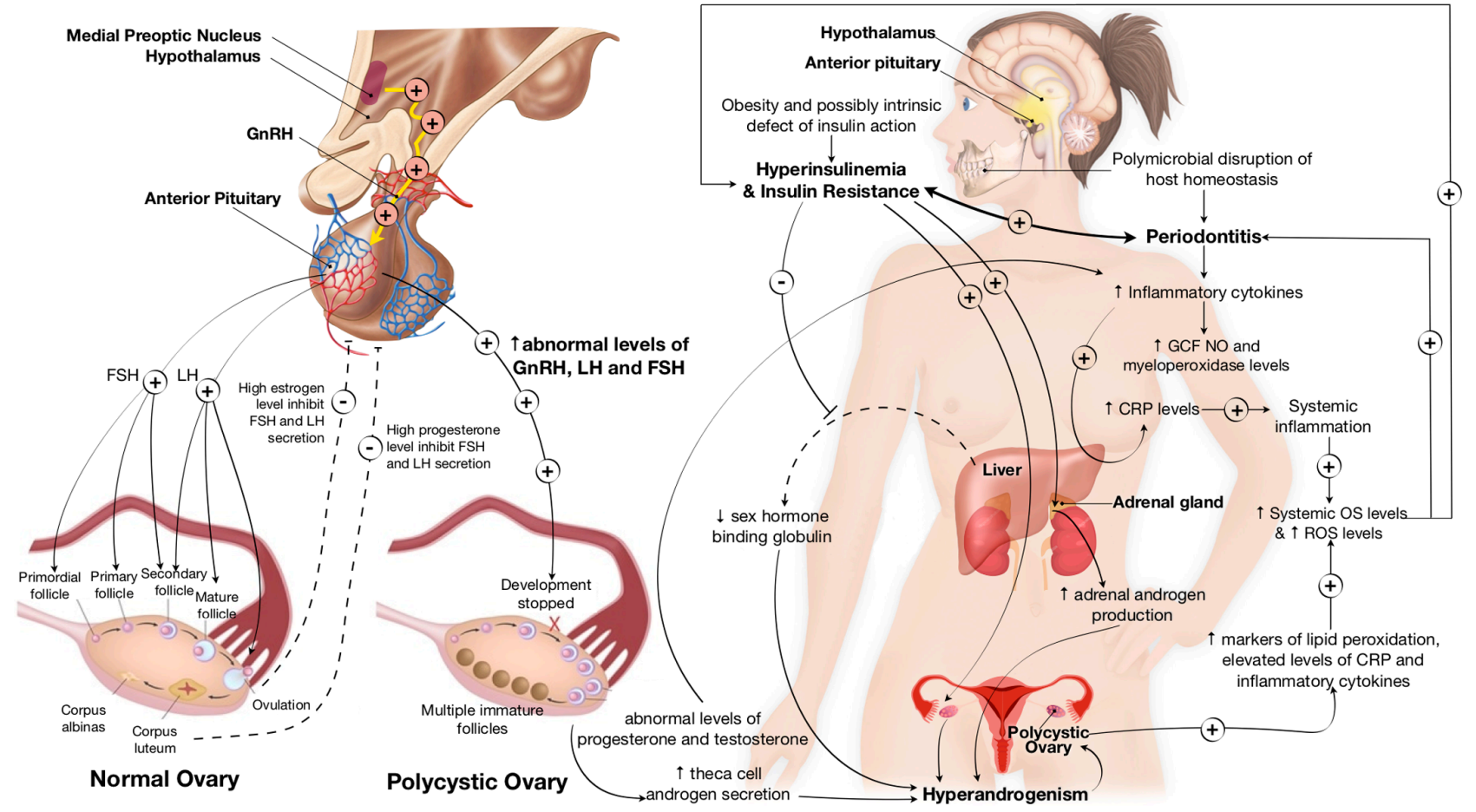

Figure 2 Polycystic ovary syndrome (PCOS) pathophysiology and the role of periodontitis. In PCOS, luteinizing hormone (LH) is key for hyperandrogenemia, and gonadotropin-releasing hormone $(\mathrm{GnRH})$ pulse generator is resistant to the negative feedback effects of progesterone. Therefore, high GnRH pulse frequencies favor the production of $\mathrm{LH}$ and limit the production of FSH, which promotes androgen production and interfere with normal follicular development. Still, PCOS is associated with insulin resistance, abnormal ovarian function and adrenal steroidogenesis, which contributes to hyperandrogenemia and female infertility. Further, PCOS women have higher serum levels of IL-6, TNF- $\alpha$, C-reactive protein (CRP), and white blood cell count. The PCOS-PD association is proposed to be grounded with common systemic inflammation, oxidative stress (OS) and insulin resistance. Further, higher levels of sex steroid hormones in PCOS patients negatively impact periodontal health.

Still, PCOS is characterized by excessive levels of sex steroid hormones that have a negative impact on PD (Dursun et al. 2011, Porwal et al. 2014, Rahiminejad et al. 2015, Hameed \& Ahmend 2017, Najah et al. 2017, Saglam et al. 2017, Işık et al. 2020) due to the presence of androgens, estrogen and progesterone receptors in the gingival tissues (Parkar et al. 1996, Gornstein et al. 1999, Kawahara \& Shimazu 2003). It seems that estrogen and progesterone changes modify the gingival tissues, leading to a higher vascular permeability and decreased keratinization of the gingival epithelium (Parkar et al. 1996, Gornstein et al. 1999, Kawahara \& Shimazu 2003).

Although several studies had shed light on the association between PCOS and PD, the relationship between PD and infertility in women with PCOS still remains to be fully elucidated (Kellesarian et al. 2017, Tong et al. 2019). Despite the lack of longer prospective studies, a recent investigation on women with both PCOS and PD has assessed the impact of PD treatment with standard Myo-inositol (MI) on systemic conditions (Deepti et al. 2017). The results of this randomised clinical trial showed that treating PD with $\mathrm{MI}$ reduced systemic inflammation and improved metabolic parameters in comparison to a therapy only with $\mathrm{MI}$ (Deepti et al. 2017). However, this study did not consider how much PCOS women were infertile at the baseline and, therefore, was not able to retrieve if resolving PD could have influenced the fertility rate.

Nevertheless, the influence of PCOS-PD link on female infertility is reasonable and might be grounded in (1) PCOS is associated with hyperandrogenism, hyperinsulinemia, and increased OS levels and which in turn have a negative impact on periodontal inflammation and destruction; (2) PD triggers proinflammatory and OS levels that dysregulate insulin resistance and negatively impact ovarian function.

\section{Obesity}

The adipose tissue is no longer seen as a simple stock of energy but a complex endocrine organ that produces many pro-inflammatory adipokines including hormones (such as adiponectin, leptin, and resistin) and proinflammatory cytokines (such as TNF- $\alpha$, IL-6) (Kern et al. 2003). CRP serum levels are positively correlated with BMI and obesity (Maiorino et al. 2018, Pavela et al. 2018). Therefore, obesity is considered to be a chronic 
low-grade inflammatory state (Broughton \& Moley 2017, Pavela et al. 2018, Sudhakar et al. 2018).

Obesity contributes to higher levels of insulin and consequently insulin resistance and appears to exacerbate the symptoms of PCOS (McCartney \& Marshall 2016). Furthermore, obesity has a negative effect on female infertility by HPO axis (Broughton \& Moley 2017, Slopien et al. 2019) and overproducing androgens (Rachoń \& Teede 2010). These increased androgens are highly transformed in estrogen at the periphery due to excessive adipose tissue (Jungheim \& Moley 2010). As a consequence, HPO axis is negatively feedbacked and affects gonadotropin secretion, resulting in menstrual irregularities, ovarian malfunction, and therefore, infertility states (Jungheim \& Moley 2010, Rachoń \& Teede 2010).

Similar to PCOS, obesity is also a risk factor for the onset and worsening of PD due to an excessive levels of sex steroid hormones and higher levels of systemic inflammation (Chaffee \& Weston 2010, Keller et al. 2015, Broughton \& Moley 2017, Martinez-Herrera et al. 2017, Khan et al. 2018). Obesity increases the risk for the colonization of red complex periodontal microorganisms, which in turn may further lead to the onset of periodontal inflammation (Suresh et al. 2017). A recent evidence-based study concluded that obese patients have $30 \%$ higher risk of having PD and patients with PD have an average difference of $2.74 \mathrm{~kg} / \mathrm{m}^{2}$ on $\mathrm{BMl}$ mean than non-PD patients
(Moura-Grec et al. 2014). Additionally, obese patients with PD have elevated TNF- $\alpha$ and IL-1B GCF levels compared to non-obese PD individuals and, therefore, a higher localized proinflammatory state (Akram et al. 2016) (Fig. 3).

An underlying common characteristic is the subclinical inflammation caused by obese states. As previously discussed in this review, a subclinical inflamed organism will contribute to worsen PD status (Suvan et al. 2011), and this might explain a possible mediation effect of PD on infertile conditions. Also, increased concentration of adipocytes may dysregulate immune responses (Falagas \& Kompoti 2006) resulting in increased PD susceptibility and exaggerated host immune responses (Suvan et al. 2011).

However, the effect of obesity and PD simultaneously on female infertility is still yet to be fully clarified, and future studies should be performed to assess this possible association using multivariate logistic regression or even mediation analysis. Further, such association might be due to the increase of inflammatory cytokines and the inflammatory burden at the systemic level, which may hamper time to conception.

\section{Endometriosis}

EM is one of the most intriguing gynaecological diseases and remains a challenging condition to treat

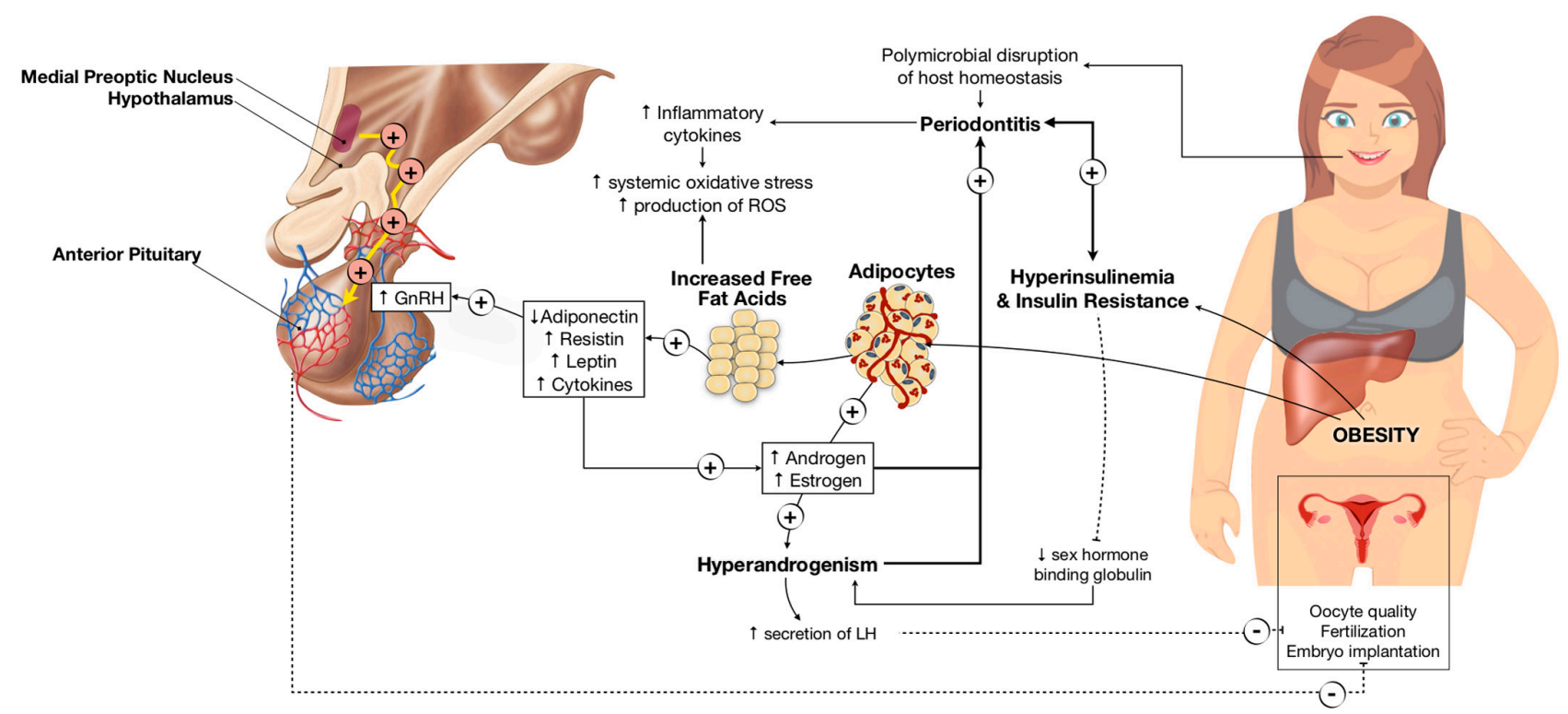

Figure 3 Suggested hypothesis of periodontitis in obese patients may lead to ovarian dysfunction. Obesity and increased body mass index (BMI) in women stimulate multiple aspects of lipotoxicity, such as intracellular lipid accumulation, inflammatory responses, and oxidative stress (OS). Alter levels of adipokines, such as leptin, in the obese state can affect steroidogenesis and directly affect the developing embryo, and can alter the function of hypothalamic-pituitary-ovarian (HPO) axis. Further, obesity is related to higher circulating levels of insulin, which stimulus the ovarian production of androgen. These androgens are aromatized to estrogen at high rates in the periphery due to excess adipose tissue, leading to negative feedback on the HPO axis and affecting gonadotropin production. Furthermore, the excessive levels of sex steroid hormones are linked to PD, that in turn increases the periodontal inflammation and increases the OS. The sum of systemic inflammation induces inflammatory responses in other tissues including the ovary. 
(Bullon \& Navarro 2017). It is a chronic inflammatory and an oestrogen-dependent disorder (Giudice \& Kao 2004, Burney \& Giudice 2012, Hickey et al. 2014, Vercellini et al. 2014, Vallvé-Juanico et al. 2019), characterized by the presence of endometrial tissue outside the uterine cavity and mainly found attached to sites within the pelvic peritoneum (Giudice \& Kao 2004, Greene et al. 2016). EM is estimated to affect $3-10 \%$ of women in the reproductive age group (Burney \& Giudice 2012, Jiang et al. 2016) and also in 50-57\% of infertile women (Kavoussi et al. 2009, Meuleman et al. 2009).

Infertility due to EM has been widely investigated and multiple pathways are on its cause, such as inflammatory processes, anatomical distortions, local endocrine alterations and OS (Van Langendonckt et al. 2002, Agarwal et al. 2005, 2012, Gupta et al. 2006, De Ziegler et al. 2010, Visioli \& Hagen 2011, Scutiero et al. 2017, Li et al. 2019).

An association between EM and PD has been proposed via inflammatory and OS mechanisms, though only two cross-sectional studies could provide such information (Kavoussi et al. 2009, Thomas et al. 2018). In particular, women suffering from EM had a 57\% higher risk of having diagnosed PD (Kavoussi et al. 2009). Also, moderate-to-severe PD was found to be higher among women with EM (Thomas et al. 2018).

Similarly to the PD-PCOS association, EM also promotes a subclinical inflammatory status, with the increase of cytokines and pro-inflammatory markers such as IL-1 beta, IL6, IL-8, TNF- $\alpha$, that might complicate PD condition with higher periodontal tissue destruction (Kavoussi et al. 2009, Cekici et al. 2014). On the other hand, no studies have investigated whether PD might contribute towards the onset or progression of EM. Nevertheless, the rationale that PD might be a direct cause of intrauterine and chorionic tissues infection through bacterial spreading has been demonstrated (Gonçalves et al. 2002, Barak et al. 2007, Katz et al. 2009, Fardini et al. 2010, Hasegawa-Nakamura et al. 2011). Therefore, the hypothesis that PD might trigger a local immune reaction aside with the installed subclinical inflammatory state in EM is conceivable though it shall be investigated indeed.

\section{Bacterial vaginosis}

Vaginal microbiota usually changes throughout the menstrual cycle and it depends on vaginal hygiene, sexual activity, use of intimate products, hormonal contraception, and lubricant use (Gajer et al. 2012). Nevertheless, greater microbiota stability is associated with the estradiol peak at ovulation and progesterone rise in the midluteal phase (Gajer et al. 2012).

The dysbiosis of vaginal microbiota can result in BV. This condition is highly prevalent, affecting nearly $30 \%$ of women during the reproductive years (Allsworth \& Peipert 2007) and it is described by a decrease in the commonly predominant Lactobacillus bacterial species, and an increase in anaerobic microbiome (Fredricks et al. 2005). Typically asymptomatic, the most common symptoms are discharge and odor (Klebanoff et al. 2006). Although not fully understand (Koumans et al. 2007), BV etiology is currently attributed to hormonal disturbances (Schwebke et al. 1996, Keane et al. 1997, Wilson et al. 2002). From the obstetric view, BV was associated with abortion (Ralph et al. 1999, van Oostrum et al. 2013, Isik et al. 2016, Carlsson et al. 2018, Haahr et al. 2019), implantation failure (Moreno et al. 2016), premature rupture of membranes and preterm birth (Yudin 2005). However, the link between BV and woman infertility is still not firmly established (van Oostrum et al. 2013, Haahr et al. 2019).

The female reproductive tract microbiota is not confined to the vaginal compartment but also in the uterus and endometrium (Swidsinski et al. 2013, Mitchell et al. 2015). Although endometrial microbiota has particular species and the bacterial load is significantly lower compared to vaginal area (Moreno et al. 2016, Bedaiwy 2019), vaginal microbiota appears to be an important source of ascending bacterial colonization (Swidsinski et al. 2013, Mitchell et al. 2015). BV was significantly related to tubal factor infertility among in vitro fertilization (IVF) patients (van Oostrum et al. 2013, Haahr et al. 2019). Despite these results highlighting the biological plausibility of bacterial ascending to the upper genital tract and cause subclinical infection and inflammation (Haahr et al. 2019), it is imperative to conduct more research before inferring a definitive causal relationship.

Some studies propose that the vaginal Lactobacillus genus produces lactic acid and short-chain fatty acids, and this homeostasis environment at $\mathrm{pH} \leq 4.5$ prevents the dysbiosis in healthy women (Skarin \& Sylwan 1986, Yamamoto et al. 2009). The mechanism that occurs in the endometrium apparently does not have the same function because no correlation was found in the $\mathrm{pH}$ levels of endometrial fluid samples and endometrial microbiota (Moreno et al. 2016). Thus, it is important to assess how bacterial endometrial dysbiosis can trigger an inflammatory response, direct production of microbial metabolites and/or enzymes capable of inducing major cell pathways in the endometrial epithelium that affects the adhesion of the blastocyst to the epithelial endometrial wall (Dominguez et al. 2010, Cha et al. 2012).

While not equal, there are microbial similarities between the oral and vaginal environments in the presence of both PD and BV, respectively (Genco 1992, Cauci 2004). This relationship may show common pathophysiology mechanisms, for instance, deficient host response to infection (Genco 1992, Cauci 2004, Pretorius et al. 2007). Yet, PD and BV may be related through the similarity in the microbiota, in particular, Prevotella species and via Prevotella-mediated 
inflammation (Larsen 2017, Coyne et al. 2019). On the one hand, Prevotella stimulate the release of IL-1b, IL- 6 and IL-23 by dendritic cells through Toll-like receptor 2 (TLR2), that mediates IL-17 production by T helper 17 (Th17) cells and in turn activate neutrophils (Larsen 2017). On the other hand, recently discovered peptide toxins secreted by Prevotella may play an important role, contributing to the widespread inflammation (Coyne et al. 2019). Consequently, Prevotella-mediated chronic inflammation leads to localized bone loss and tissue destruction in PD and endotoxemia via lipopolysaccharides. Local inflammation caused in both pathologies disseminates and may collapse systemic health (Larsen 2017).

Comprehensively, the hypotheses for contamination are the haematogenous spread or oral-genital direct transfer (Hill 1993, Edwards \& Carne 1999, Harville et al. 2004); however, the relationship between these two pathologies remains poorly understood.

\section{Hormonal dysregulation through chronic kidney disease}

CKD is a general term for heterogeneous disorders affecting the kidney's function and structures (Levey \& Coresh 2012, Ricardo et al. 2015, Webster et al. 2017). The discrepancy in disease expression is connected to etiology, progression rate and severity (Levey \& Coresh 2012). Nowadays, the definition of CKD is based on the presence of kidney damage or decreased kidney function for 3 months or more, irrespective of clinical diagnosis (National Kidney Foundation 2002, Vassalotti et al. 2007), and it has been found that CKD is developed through chronic inflammation in the renal tissues (Chopra \& Sivaraman 2019). The burden of early stages of CKD is difficult to measure because CKD is found mostly before the onset of symptoms (Stevens \& Levey 2009), and its 10-15\% worldwide prevalence continues to rise, particularly among female patients (Dumanski \& Ahmed 2019, Elhoseny et al. 2019).

Among its vital roles, kidney is responsible for sex hormones turnover and its dysfunction directly influences the HPO axis, resulting in progressive fertility loss (Finkelstein et al. 2007, Kuczera et al. 2015, Ahmed \& Ramesh 2016, Palmer \& Clegg 2017, Dumanski \& Ahmed 2019). Regarding this loss of fertility secondary to CKD, luteinizing hormone ( $\mathrm{LH})$ and the folliclestimulating hormone (FSH) increase but the levels of estrogen and progesterone dwindle, culminating in an abnormal hormonal cycle (Dumanski \& Ahmed 2019). Furthermore, CKD female patients may also experience anovulation, reduced ovarian reserves, menstrual disorders, abnormal endometrium, reduced libido, and sexual dysfunction (Kuczera et al. 2015, Palmer \& Clegg 2017, Dumanski \& Ahmed 2019). As a consequence, the rates of spontaneous pregnancy in CKD patients decrease to $1-7 \%$, rather than the physiological $65-94 \%$ (Hou 2007).

Remarkably, PD and CKD share a relationship based on bacterial spreading and cytokines dissemination from periodontal pockets through the bloodstream (Kshirsagar et al. 2007, Fisher et al. 2008, Chambrone et al. 2013, Ismail et al. 2015, Ricardo et al. 2015, Akram et al. 2016, Sharma et al. 2016, Almeida et al. 2017, Chopra \& Sivaraman 2019, Deschamps-Lenhardt et al. 2019). Moreover, a recent systematic review concluded that patients with PD have a risk of 1.49-2.39 times higher to develop CKD, and this risk is directly related to the severity of periodontal destruction (Deschamps-Lenhardt et al. 2019). Notwithstanding, the PD treatment in CKD patients might partially recover kidney function through the reduction of the inflammatory state, in particular, improvement of glomerular filtration rate, creatinine levels, and endothelial function (Deschamps-Lenhardt et al. 2019).

Since CKD is one of the causes of female infertility, and $\mathrm{PD}$ is a well-established modifiable risk factor towards CKD, it is reasonable to consider that PD might worsen the women infertility secondary to CKD. Thus, it is important to consider periodontal screening in the multidisciplinary management of infertile women due to CKD, and future studies should investigate this possible association.

\section{Age}

Age is undoubtedly related to female fertility (Eijkemans et al. 2014), and the age at last birth (ALB) curve shows a gradual increase to 35 and 40 years old, and after that a rapidly increase in fertility woman's loss (Leridon 1977, Spira 1988, Wood 1989, Eijkemans et al. 2014). In addition to the latter, age is also a risk factor for onset and development of PD (van der Velden 1984, Rajendran et al. 2013, Ebersole et al. 2016). We find relevant to emphasize that the age peak of PD onset is placed at 38 years old (Kassebaum et al. 2014) (ranging 25-45 years of age) which may overlap the time interval of the major likelihood of conception. Further, women using hormonal contraceptives have higher association with PD (Tilakaratne et al. 2000, Mullally et al. 2007, Prachi et al. 2019). Therefore, the risk timeline for PD onset matches the timeline for pregnancy, and this factor should not be forgotten.

\section{Assisted reproductive technologies}

Many couples continue to be diagnosed with idiopathic infertility or receive descriptive diagnoses that do not provide a cause for their defect (Cousineau and Domar 2007, Ray et al. 2012, Djurovic et al. 2018), and therefore hampering their infertility problem (Matzuk \& Lamb 2008). Besides, whether the etiology is known or 
not, the advances in ART have overcome this problem, though ART is used to make it possible to conceive and is not a cure to the causes of infertility (Qin et al. 2017). However, females believe that fertility can be manipulated through ART (Te Velde et al. 2010), and many women believe erroneously that infertility care can address the fertility decline associated with age (Maheshwari et al. 2008).

ART range from a simple oral administration of drugs to stimulate ovulation, to more invasive techniques such as intrauterine insemination to install a processed sample of sperm into the uterine cavity directly, and IVF (Qin et al. 2017, Sullivan-Pyke et al. 2017)

Nowadays, 65 countries reported the use of ART during 2011, and Europe had the highest number of participants (41.6\%), followed by Asia (33.9\%) and North America (16\%) (Adamson et al. 2018). Besides, evidence confirms that pregnancies resulting from IVF and/or intrauterine insemination have worse adverse perinatal outcomes than spontaneous conceptions, after controlling for patient factors (Hansen \& Bower 2014). These outcomes include an risk of low birth weight, preterm birth, stillbirth, perinatal mortality, admission to a neonatal intensive care unit, antepartum haemorrhage, hypertensive disorders during pregnancy, gestational DM (Helmerhorst et al. 2004, Chung et al. 2006, McDonald et al. 2010, Pandey et al. 2012, Pinborg et al. 2013, Davies et al. 2017), and also congenital anomalies, imprinting disorders (Vermeiden \& Bernardus 2013), autism spectrum disorders (Lehti et al. 2013) and neurodevelopmental disorders (Strömberg et al. 2002).

Despite the lower number of available literature, the stimulated ovulation via a hormonal overload in ART might turn women more prone to gingival inflammation (Haytaç et al. 2004, Vasudevan et al. 2013, Lalasa et al. 2014, Pavlatou 2014, Smadi 2017), warranting constant periodontal monitoring. Notwithstanding, PD may act as a modifiable risk factor limiting conception (Hart et al. 2012, Nwhator et al. 2014, Paju et al. 2017), and periodontal therapy on women prior to conception reduces significantly adverse birth outcomes (Jiang et al. 2013). Since PD is common among adults (Albandar \& Rams 2002, Dye 2012, Petersen \& Ogawa 2012) and there is a possible link between PD and pregnancy outcome (Wu et al. 2015, Abariga \& Whitcomb 2016, Puertas et al. 2017) in a world where the infertility rates are high, highlighting its relation with infertility treatments becomes very relevant.

Overall, it should be noted that ART is not harmless (Zhu et al. 2006, Wisborg et al. 2010, Zollner \& Dietl 2013, Morency et al. 2016, Iwashima et al. 2017). Therefore, it is crucial to investigate the real implication of $\mathrm{PD}$ in female infertility. Besides, if proven a negative impact of PD in women seeking ART, then periodontal consultations might be of importance for prenatal care, possibly increasing fertility success and avoiding complex and invasive treatment such as ART.

\section{Conclusions}

This comprehensive review has brought to light gaining evidence that links female infertility-related conditions as a modifiable risk factor towards PD. Further research is needed to clarify this causal relationship as well the mechanisms underlined. The current evidence does not support a role for PD in on female infertility-related conditions.

\section{Declaration of interest}

The authors declare that there is no conflict of interest that could be perceived as prejudicing the impartiality of the research reported.

\section{Funding}

This work did not receive any specific grant from any funding agency in the public, commercial, or not-for-profit sector.

\section{Author contribution statement}

V M, J B conceived and planned the review article. J L, M P, $J B$ and $V M$ have performed the review of the literature. J $L$, $M P, J B, L P, J J M$ and V M drafted, provide critical feedback and helped shape the research and manuscript. J L and M P are equally first authors.

\section{References}

Abariga SA \& Whitcomb BW 2016 Periodontitis and gestational diabetes mellitus: a systematic review and meta-analysis of observational studies. BMC Pregnancy and Childbirth 16 344. (https://doi.org/10.1186/ s12884-016-1145-z)

Adamson GD, Mouzon J, Chambers GM, Zegers-Hochschild F, Mansour R, Ishihara O, Banker M \& Dyer S 2018 International committee for monitoring assisted reproductive technology: world report on assisted reproductive technology, 2011. Fertility and Sterility 110 1067-1080. (https://doi.org/10.1016/j.fertnstert.2018.06.039)

Agarwal A, Aponte-Mellado A, Premkumar BJ, Shaman A \& Gupta S 2012 The effects of oxidative stress on female reproduction: a review. Reproductive Biology and Endocrinology 10 49. (https://doi. org/10.1186/1477-7827-10-49)

Agarwal A, Gupta S \& Sharma RK 2005 Role of oxidative stress in female reproduction. Reproductive Biology and Endocrinology 3 28. (https:// doi.org/10.1186/1477-7827-3-28)

Ahmed SB \& Ramesh S 2016 Sex hormones in women with kidney disease. Nephrology, Dialysis, Transplantation 31 1787-1795. (https:// doi.org/10.1093/ndt/gfw084)

Akcalı A, Bostanci N, Özçaka Ö, Gümüş P, Öztürk-Ceyhan B, Tervahartiala T, Husu H, Buduneli N, Sorsa T \& Belibasakis GN 2017 Gingival inflammation and salivary or serum granulocytesecreted enzymes in patients with polycystic ovary syndrome. Journal of Periodontology 88 1145-1152. (https://doi.org/10.1902/ jop.2017.170043)

Akcali A, Huck O, Tenenbaum H, Davideau JL\& Buduneli N 2013 Periodontal diseases and stress: a brief review. Journal of Oral Rehabilitation $\mathbf{4 0}$ 60-68. (https://doi.org/10.1111/j.1365-2842.2012.02341.x)

Akcall A, Bostanci N, Özçaka Ö, Öztürk-Ceyhan B, Gümüş P, Tervahartiala T, Husu H, Buduneli N, Sorsa T \& Belibasakis GN 2015 Elevated matrix metalloproteinase-8 in saliva and serum in polycystic ovary syndrome and association with gingival inflammation. Innate Immunity 21 619-625. (https://doi.org/10.1177/1753425915572172) 
Akram Z, Abduljabbar T, Abu Hassan MI, Javed F \& Vohra F 2016 Cytokine profile in chronic periodontitis patients with and without obesity: a systematic review and meta-analysis. Disease Markers 20164801418. (https://doi.org/10.1155/2016/4801418)

Albandar JM \& Rams TE 2002 Global epidemiology of periodontal diseases: an overview. Periodontology 200029 7-10. (https://doi. org/10.1034/j.1600-0757.2002.290101.x)

Albandar JM, Susin C \& Hughes FJ 2018 Manifestations of systemic diseases and conditions that affect the periodontal attachment apparatus : case definitions and diagnostic considerations. Journal of Periodontology $\mathbf{8 9}$ (Supplement 1) 171-189. (https://doi.org/10.1002/JPER.16-0480)

Allsworth JE \& Peipert JF 2007 Prevalence of bacterial vaginosis: 2001-2004 national health and nutrition examination survey data Obstetrics and Gynecology 109 114-120. (https://doi.org/10.1097/01. AOG.0000247627.84791.91)

Almeida S, Figueredo CM, Lemos C, Bregman R \& Fischer RG 2017 Periodontal treatment in patients with chronic kidney disease: pilot study. Journal of Periodontal Research 52 262-267. (https://doi. org/10.1111/jre.12390)

Azziz R 2016 PCOS in 2015: new insights into the genetics of polycystic ovary syndrome. Nature Reviews: Endocrinology 12 74-75. (https://doi. org/10.1038/nrendo.2015.230)

Barak S, Oettinger-Barak O, Machtei EE, Sprecher H \& Ohel G 2007 Evidence of periopathogenic microorganisms in placentas of women with preeclampsia. Journal of Periodontology 78 670-676. (https://doi. org/10.1902/jop.2007.060362)

Barros SP, Williams R, Offenbacher S \& Morelli T 2016 Gingival crevicular fluid as a source of biomarkers for periodontitis. Periodontology 200070 53-64. (https://doi.org/10.1111/prd.12107)

Bartold PM \& Van Dyke TE 2017 Host modulation: controlling the inflammation to control the infection. Periodontology 200075 317-329. (https://doi.org/10.1111/prd.12169)

Bedaiwy MA 2019 Endometrial macrophages, endometriosis, and microbiota: time to unravel the complexity of the relationship. Fertility and Sterility 112 1049-1050. (https://doi.org/10.1016/j. fertnstert.2019.09.021)

Botelho J, Machado V, Proença L, Bellini DH, Chambrone L, Alcoforado G \& Mendes JJ 2020b The impact of nonsurgical periodontal treatment on oral health-related quality of life: a systematic review and meta-analysis. Clinical Oral Investigations 24 585-596. (https://doi.org/10.1007/ s00784-019-03188-1)

Botelho J, Machado V, Proença L \& Mendes JJ 2020a The 2018 periodontitis case definition improves accuracy performance of fullmouth partial diagnostic protocols. Scientific Reports 10 7093. (https:// doi.org/10.1038/s41598-020-63700-6)

Broughton DE \& Moley KH 2017 Obesity and female infertility: potential mediators of obesity's impact. Fertility and Sterility 107 840-847. (https:// doi.org/10.1016/j.fertnstert.2017.01.017)

Buduneli N \& Scott DA 2018 Tobacco-induced suppression of the vascular response to dental plaque. Molecular Oral Microbiology 33 271-282. (https://doi.org/10.1111/omi.12228)

Bullon P \& Navarro JM 2017 Inflammasome as a key pathogenic mechanism in endometriosis. Current Drug Targets 18 997-1002. (https://doi.org/10. 2174/1389450117666160709013850)

Burney RO \& Giudice LC 2012 Pathogenesis and pathophysiology of endometriosis. Fertility and Sterility 98 511-519. (https://doi. org/10.1016/j.fertnstert.2012.06.029)

Buset SL, Walter C, Friedmann A, Weiger R, Borgnakke WS \& Zitzmann NU 2016 Are periodontal diseases really silent? A systematic review of their effect on quality of life. Journal of Clinical Periodontology 43 333-344. (https://doi.org/10.1111/jcpe.12517)

Cardoso EM, Reis C \& Manzanares-Céspedes MC 2018 Chronic periodontitis, inflammatory cytokines, and interrelationship with other chronic diseases. Postgraduate Medicine 130 98-104. (https://doi.org/1 $0.1080 / 00325481.2018 .1396876)$

Carlsson I, Breding K \& Larsson PG 2018 Complications related to induced abortion: a combined retrospective and longitudinal follow-up study. BMC Women's Health 18 158. (https://doi.org/10.1186/s12905-018-0645-6)

Caserta D, Adducchio G, Picchia S, Ralli E, Matteucci E \& Moscarini M 2014 Metabolic syndrome and polycystic ovary syndrome: an intriguing overlapping. Gynecological Endocrinology 30 397-402. (https://doi.org/ $10.3109 / 09513590.2014 .887673)$
Cauci S 2004 Vaginal immunity in bacterial vaginosis. Current Infectious Disease Reports 6 450-456. (https://doi.org/10.1007/s11908-004-0064-8)

Cekici A, Kantarci A, Hasturk H \& Van Dyke TE 2014 Inflammatory and immune pathways in the pathogenesis of periodontal disease. Periodontology 200064 57-80. (https://doi.org/10.1111/prd.12002)

Cha J, Sun X \& Dey SK 2012 Mechanisms of implantation: strategies for successful pregnancy. Nature Medicine 18 1754-1767. (https://doi. org/10.1038/nm.3012)

Chaffee BW \& Weston SJ 2010 Association between chronic periodontal disease and obesity: a systematic review and meta-analysis. Journal of Periodontology 81 1708-1724. (https://doi.org/10.1902/ jop.2010.100321)

Chambrone L, Foz AM, Guglielmetti MR, Pannuti CM, Artese HPC, Feres M \& Romito GA 2013 Periodontitis and chronic kidney disease: a systematic review of the association of diseases and the effect of periodontal treatment on estimated glomerular filtration rate. Journal of Clinical Periodontology $\mathbf{4 0}$ 443-456. (https://doi.org/10.1111/ jcpe.12067)

Chan S, Pasternak GM \& West MJ 2017 The place of periodontal examination and referral in general medicine. Periodontology 200074 194-199. (https://doi.org/10.1111/prd.12199)

Chen M, Cai W, Zhao S, Shi L, Chen Y, Li X, Sun X, Mao Y, He B, Hou Y et al. 2019 Oxidative stress-related biomarkers in saliva and gingival crevicular fluid associated with chronic periodontitis: a systematic review and meta-analysis. Journal of Clinical Periodontology $\mathbf{4 6}$ 608-622. (https://doi.org/10.1111/jcpe.13112)

Chopra A \& Sivaraman K 2019 An update on possible pathogenic mechanisms of periodontal pathogens on renal dysfunction. Critical Reviews in Microbiology 45 1-25. (https://doi.org/10.1080/104084 1X.2018.1553847)

Chung K, Coutifaris C, Chalian R, Lin K, Ratcliffe SJ, Castelbaum AJ, Freedman MF \& Barnhart KT 2006 Factors influencing adverse perinatal outcomes in pregnancies achieved through use of in vitro fertilization. Fertility and Sterility 86 1634-1641. (https://doi.org/10.1016/j. fertnstert.2006.04.038)

Cousineau TM \& Domar AD 2007 Psychological impact of infertility. Best Practice and Research: Clinical Obstetrics and Gynaecology 21 293-308. (https://doi.org/10.1016/j.bpobgyn.2006.12.003)

Coyne MJ, Béchon N, Matano LM, McEneany VL, Chatzidaki-Livanis M \& Comstock LE 2019 A family of anti-bacteroidales peptide toxins widespread in the human gut microbiota. Nature Communications 103460. (https://doi.org/10.1038/s41467-019-11494-1)

D'Aiuto F, Gkranias N, Bhowruth D, Khan T, Orlandi M, Suvan J, Masi S, Tsakos G, Hurel S, Hingorani AD et al. 2018 Systemic effects of periodontitis treatment in patients with type 2 diabetes: a 12 month, single-centre, investigator-masked, randomised trial. Lancet: Diabetes and Endocrinology 6 954-965. (https://doi.org/10.1016/S22138587(18)30038-X)

D'Aiuto F, Orlandi M \& Gunsolley JC 2013 Evidence that periodontal treatment improves biomarkers and CVD outcomes. Journal of Periodontology 84 (Supplement) S85-S105. (https://doi.org/10.1902/ jop.2013.134007)

Darveau RP 2010 Periodontitis: a polymicrobial disruption of host homeostasis. Nature Reviews: Microbiology 8 481-490. (https://doi. org/10.1038/nrmicro2337)

Davies MJ, Rumbold AR \& Moore VM 2017 Assisted reproductive technologies: a hierarchy of risks for conception, pregnancy outcomes and treatment decisions. Journal of Developmental Origins of Health and Disease 8 443-447. (https://doi.org/10.1017/S2040174417000526)

De Ziegler D, Borghese B \& Chapron C 2010 Endometriosis and infertility: pathophysiology and management. Lancet 376 730-738. (https://doi. org/10.1016/S0140-6736(10)60490-4)

Deepti, Tewari S, Narula SC, Singhal SR \& Sharma RK 2017 Effect of nonsurgical periodontal therapy along with myo-inositol on high-sensitivity C-reactive protein and insulin resistance in women with polycystic ovary syndrome and chronic periodontitis: a randomized controlled trial. Journal of Periodontology 88 999-1011. (https://doi.org/10.1902/ jop.2017.170121)

Deschamps-Lenhardt S, Martin-Cabezas R, Hannedouche T \& Huck O 2019 Association between periodontitis and chronic kidney disease: systematic review and meta-analysis. Oral Diseases 25 385-402. (https:// doi.org/10.1111/odi.12834) 
Djurovic J, Stamenkovic G, Todorovic J, Aleksic N \& Stojkovic O 2018 Polymorphisms and haplotypes in VDR gene are associated with female idiopathic infertility. Human Fertility 23 1-10. (https://doi.org/10.1080/1 4647273.2018.1515503)

Dominguez F, Gadea B, Mercader A, Esteban FJ, Pellicer A \& Simón C 2010 Embryologic outcome and secretome profile of implanted blastocysts obtained after coculture in human endometrial epithelial cells versus the sequential system. Fertility and Sterility 93 774-782.e1. (https://doi. org/10.1016/j.fertnstert.2008.10.019)

Dos Santos ACS, Soares NP, Costa EC, De Sá JCF, Azevedo GD \& Lemos TMAM 2015 The impact of body mass on inflammatory markers and insulin resistance in polycystic ovary syndrome. Gynecological Endocrinology 31 225-228. (https://doi.org/10.3109/09513590.2014.9 76546)

Dumanski SM \& Ahmed SB 2019 Fertility and reproductive care in chronic kidney disease. Journal of Nephrology 32 39-50. (https://doi. org/10.1007/s40620-018-00569-9)

Dumesic DA, Oberfield SE, Stener-Victorin E, Marshall JC, Laven JS \& Legro RS 2015 Scientific statement on the diagnostic criteria, epidemiology, pathophysiology, and molecular genetics of polycystic ovary syndrome. Endocrine Reviews 36 487-525. (https://doi. org/10.1210/er.2015-1018)

Dunaif A 1997 Insulin resistance in polycystic ovary syndrome: mechanism and implications for pathogenesis. Endocrine Reviews 18 774-800. (https://doi.org/10.1210/edrv.18.6.0318)

Dursun E, Akaln FA, Güncü GN, Çnar N, Aksoy DY, Tözüm TF, Kilinc K \& Yildiz BO 2011 Periodontal disease in polycystic ovary syndrome. Fertility and Sterility 95 320-323. (https://doi.org/10.1016/j. fertnstert.2010.07.1052)

Dye BA 2012 Global periodontal disease epidemiology. Periodontology 200058 10-25. (https://doi.org/10.1111/j.1600-0757.2011.00413.x)

Ebersole JL, Dawson D, Emecen-Huja P, Nagarajan R, Howard K, Grady ME, Thompson K, Peyyala R, Al-Attar A, Lethbridge K et al. 2017 The periodontal war: microbes and immunity. Periodontology 200075 52-115. (https://doi.org/10.1111/prd.12222)

Ebersole JL, Graves CL, Gonzalez OA, Dowson III D, Morford LA, Huja PE, Hartsfield Jr JK, Huja SS, Pandruvada S \& Wallet SM 2016 Aging, inflammation, immunity and periodontal disease. Periodontology 200072 54-75. (https://doi.org/10.1111/prd.12135)

Ebersole JL, Schuster JL, Stevens J, Dawson D, Kryscio RJ, Lin Y, Thomas MV \& Miller CS 2013 Patterns of salivary analytes provide diagnostic capacity for distinguishing chronic adult periodontitis from health. Journal of Clinical Immunology 33 271-279. (https://doi. org/10.1007/s10875-012-9771-3)

Edwards S \& Carne C 1999 Oral sex and the transmission of non-viral STIs. Sexually Transmitted Infections 74 95-100.

Eijkemans MJC, Van Poppel F, Habbema DF, Smith KR, Leridon H \& Te Velde ER 2014 Too old to have children? Lessons from natural fertility populations. Human Reproduction 29 1304-1312. (https://doi. org/10.1093/humrep/deu056)

Elhoseny M, Shankar K \& Uthayakumar J 2019 Intelligent diagnostic prediction and classification system for chronic kidney disease. Scientific Reports 9 9583. (https://doi.org/10.1038/s41598-019-46074-2)

Escobar-Morreale HF, Luque-Ramírez M \& González F 2011 Circulating inflammatory markers in polycystic ovary syndrome: a systematic review and metaanalysis. Fertility and Sterility 95 1048.e1-1058.e1. (https://doi. org/10.1016/j.fertnstert.2010.11.036)

Falagas ME \& Kompoti M 2006 Obesity and infection. Lancet: Infectious Diseases 6 438-446. (https://doi.org/10.1016/S1473-3099(06)70523-0)

Fardini Y, Chung P, Dumm R, Joshi N \& Han YW 2010 Transmission of diverse oral bacteria to murine placenta: evidence for the oral microbiome as a potential source of intrauterine infection. Infection and Immunity 78 1789-1796. (https://doi.org/10.1128/IAI.01395-09)

Finkelstein FO, Shirani S, Wuerth D \& Finkelstein SH 2007 Therapy insight: sexual dysfunction in patients with chronic kidney disease. Nature Clinical Practice: Nephrology 3 200-207. (https://doi.org/10.1038/ ncpneph0438)

Fisher MA, Taylor GW, Shelton BJ, Jamerson KA, Rahman M, Ojo AO \& Sehgal AR 2008 Periodontal disease and other nontraditional risk factors for CKD. American Journal of Kidney Diseases 51 45-52. (https://doi. org/10.1053/j.ajkd.2007.09.018)
Fredricks DN, Fiedler TL \& Marrazzo JM 2005 Molecular identification of bacteria associated with bacterial vaginosis. New England Journal of Medicine 353 1899-1911. (https://doi.org/10.1056/NEJMoa043802)

Gajer P, Brotman RM, Bai G, Sakamoto J, Schütte UME, Zhong X, Koenig SSK, Fu L, Ma ZS, Zhou X et al. 2012 Temporal dynamics of the human vaginal microbiota. Science Translational Medicine 4132 ra52. (https://doi.org/10.1126/scitranslmed.3003605)

Garlet GP 2010 Destructive and protective roles of cytokines in periodontitis: a re-appraisal from host defense and tissue destruction viewpoints. Journal of Dental Research 89 1349-1363. (https://doi. org/10.1177/0022034510376402)

Genco RJ 1992 Host responses in periodontal diseases: current concepts. Journal of Periodontology 63(Supplement) 338-355. (https://doi. org/10.1902/jop.1992.63.4s.338)

Giudice LC \& Kao LC 2004 Endometriosis. Lancet 364 1789-1799. (https:// doi.org/10.1016/S0140-6736(04)17403-5)

Gonçalves LF, Chaiworapongsa T \& Romero R 2002 Intrauterine infection and prematurity. Mental Retardation and Developmental Disabilities Research Reviews 8 3-13. (https://doi.org/10.1002/mrdd.10008)

Gonzales JR 2015 T- and B-cell subsets in periodontitis. Periodontology 200069 181-200. (https://doi.org/10.1111/prd.12090)

Gornstein RA, Lapp CA, Bustos-Valdes SM \& Zamorano P 1999 Androgens modulate interleukin- 6 production by gingival fibroblasts in vitro. Journal of Periodontology 70 604-609. (https://doi.org/10.1902/ jop.1999.70.6.604)

Greene AD, Lang SA, Kendziorski JA, Sroga-Rios JM, Herzog TJ \& Burns KA 2016 Endometriosis: where are we and where are we going? Reproduction 152 R63-R78. (https://doi.org/10.1530/REP-16-0052)

Greenwood EA \& Huddleston HG 2019 Insulin resistance in polycystic ovary syndrome: concept versus cutoff. Fertility and Sterility $\mathbf{1 1 2}$ 827-828. (https://doi.org/10.1016/j.fertnstert.2019.08.100)

Gupta S, Agarwal A, Krajcir N \& Alvarez JG 2006 Role of oxidative stress in endometriosis. Reproductive Biomedicine Online 13 126-134. (https:// doi.org/10.1016/s1472-6483(10)62026-3)

Haahr T, Zacho J, Bräuner M, Shathmigha K, Skov Jensen J \& Humaidan P 2019 Reproductive outcome of patients undergoing in vitro fertilisation treatment and diagnosed with bacterial vaginosis or abnormal vaginal microbiota: a systematic PRISMA review and meta-analysis. BJOG 126 200-207. (https://doi.org/10.1111/1471-0528.15178)

Hameed DJ \& Ahmend MA-A 2017 Evaluation of serum homocysteine and nitric oxide levels in women with polycystic ovarian syndrome and periodontal diseases. Tikrit Journal for Dental Sciences 5 57-65.

Hansen M \& Bower C 2014 The impact of assisted reproductive technologies on intra-uterine growth and birth defects in singletons. Seminars in Fetal and Neonatal Medicine 19 228-233. (https://doi. org/10.1016/j.siny.2014.03.002)

Hart R, Doherty DA, Pennell CE, Newnham IA \& Newnham JP 2012 Periodontal disease: a potential modifiable risk factor limiting conception. Human Reproduction 27 1332-1342. (https://doi.org/10.1093/humrep/ des034)

Hart RJ 2016 Physiological aspects of female fertility: role of the environment, modern lifestyle, and genetics. Physiological Reviews 96 873-909. (https://doi.org/10.1152/physrev.00023.2015)

Harville EW, Zhang J \& Hatch MC 2004 Oral sex and gum disease. Sexually Transmitted Infections 80 418-419. (https://doi.org/10.1136/ sti.2003.009027)

Hasegawa-Nakamura K, Tateishi F, Nakamura T, Nakajima Y, Kawamata K, Douchi T, Hatae M \& Noguchi K 2011 The possible mechanism of preterm birth associated with periodontopathic Porphyromonas gingivalis. Journal of Periodontal Research 46 497-504. (https://doi. org/10.1111/j.1600-0765.2011.01366.x)

Haytaç MC, Cetin T \& Seydaoglu G 2004 The effects of ovulation induction during infertility treatment on gingival inflammation. Journal of Periodontology 75 805-810. (https://doi.org/10.1902/ jop.2004.75.6.805)

Helmerhorst FM, Perquin DAM, Donker D \& Keirse MJNC 2004 Perinatal outcome of singletons and twins after assisted conception: a systematic review of controlled studies. BMJ 328 261. (https://doi.org/10.1136/ bmj.37957.560278.EE)

Hickey M, Ballard K \& Farquhar C 2014 Endometriosis. BMJ 348 g1752. (https://doi.org/10.1136/bmj.g1752) 
Hill GB 1993 Investigating the source of amniotic fluid isolates of fusobacteria. Clinical Infectious Diseases 16 (Supplement 4) S423-S424. (https://doi.org/10.1093/clinids/16.supplement_4.s423)

Hou S 2007 Historical perspective of pregnancy in chronic kidney disease. Advances in Chronic Kidney Disease 14 116-118. (https://doi. org/10.1053/j.ackd.2007.01.001)

Hull MGR 1987 Epidemiology of infertility and polycystic ovarian disease: endocrinological and demographic studies. Gynecological Endocrinology 1 235-245. (https://doi.org/10.3109/09513598709023610)

Hussain SB, Botelho J, Machado V, Zehra SA, Mendes J, Ciurtin C, Orlandi M \& Aiuto FD 2020 Is there a bidirectional association between rheumatoid arthritis and periodontitis? A systematic review and metaanalysis. Seminars in Arthritis and Rheumatism 50 414-422. (https://doi. org/10.1016/j.semarthrit.2020.01.009)

Isik G, Demirezen Ş, Dönmez HG \& Beksaç MS 2016 Bacterial vaginosis in association with spontaneous abortion and recurrent pregnancy losses. Journal of Cytology 33 135-140. (https://doi.org/10.4103/09709371.188050)

Işık Y, Telatar GY, Neşelioğlu S, Biçer C \& Gürlek B 2020 Evaluation of periodontal status in different phenotypes of polycystic ovary syndrome in untreated patients of early reproductive age: a case-control study. Journal of Obstetrics and Gynaecology Research 46 459-465. (https:// doi.org/10.1111/jog.14179)

Ismail FB, Ismail G, Dumitriu AS, Baston C, Berbecar V, Jurubita R Andronesi A, Dumitriu HT \& Sinescu I 2015 Identification of subgingival periodontal pathogens and association with the severity of periodontitis in patients with chronic kidney diseases: a cross-sectional study. BioMed Research International 2015 370314. (https://doi. org/10.1155/2015/370314)

Iwashima S, Ishikawa T \& Itoh H 2017 Reproductive technologies and the risk of congenital heart defects. Human Fertility 20 14-21. (https://doi.or g/10.1080/14647273.2016.1254352)

Jansson L \& Lavstedt S 2002 Influence of smoking on marginal bone loss and tooth loss - a prospective study over 20 years. Journal of Clinical Periodontology 29 750-756. (https://doi.org/10.1034/j.1600051x.2002.290812.x)

Jepsen S, Caton JG, Albandar JM, Bissada NF, Bouchard P, Cortellini P, Demirel K, de Sanctis M, Ercoli C, Fan J et al. 2018 Periodontal manifestations of systemic diseases and developmental and acquired conditions: consensus report of workgroup 3 of the 2017 world workshop on the classification of periodontal and peri-implant diseases and conditions. Journal of Clinical Periodontology 45 (Supplement 20) S219-S229. (https://doi.org/10.1111/jcpe.12951)

Jiang H, Xiong X, Su Y, Zhang Y, Wu H, Jiang Z \& Qian X 2013 A randomized controlled trial of pre-conception treatment for periodontal disease to improve periodontal status during pregnancy and birth outcomes. BMC Pregnancy and Childbirth 13 228. (https://doi.org/10.1186/1471-239313-228)

Jiang L, Yan Y, Liu Z \& Wang Y 2016 Inflammation and endometriosis. Frontiers in Bioscience 21 941-948. (https://doi.org/10.2741/4431)

Johannsen A, Susin C \& Gustafsson A 2014 Smoking and inflammation: evidence for a synergistic role in chronic disease. Periodontology 2000 64 111-126. (https://doi.org/10.1111/j.1600-0757.2012.00456.x)

Jungheim ES \& Moley KH 2010 Current knowledge of obesity's effects in the pre-and periconceptional periods and avenues for future research. American Journal of Obstetrics and Gynecology 203 525-530. (https:// doi.org/10.1016/j.ajog.2010.06.043)

Kassebaum NJ, Bernabé E, Dahiya M, Bhandari B, Murray CJL \& Marcenes W 2014 Global burden of severe tooth loss : a systematic review and meta-analysis. JDR Clínical Research Supplement 93 (Supplement) 20s-28s.

Katz J, Chegini N, Shiverick KT \& Lamont RJ 2009 Localization of $P$. gingivalis in preterm delivery placenta. Journal of Dental Research $\mathbf{8 8}$ 575-578. (https://doi.org/10.1177/0022034509338032)

Kavoussi SK, West BT, Taylor GW \& Lebovic DI 2009 Periodontal disease and endometriosis: analysis of the national health and nutrition examination survey. Fertility and Sterility 91 335-342. (https://doi. org/10.1016/j.fertnstert.2007.12.075)

Kawahara K \& Shimazu A 2003 Expression and intracellular localization of progesterone receptors in cultured human gingival fibroblasts. Journal of Periodontal Research 38 242-246. (https://doi.org/10.1034/j.1600$0765.2003 .00654 . x)$
Keane FEA, Ison CA \& Taylor-Robinson D 1997 A longitudinal study of the vaginal flora over a menstrual cycle. International Journal of STD and AIDS 8 489-494. (https://doi.org/10.1258/0956462971920631)

Keller A, Rohde JF, Raymond K \& Heitmann BL 2015 Association between periodontal disease and overweight and obesity: a systematic review. Journal of Periodontology 86 766-776. (https://doi.org/10.1902/ jop.2015.140589)

Kellesarian SV, Kellesarian TV, Ros Malignaggi V, Al-Askar M, Ghanem A, Malmstrom H \& Javed F 2018 a Association between periodontal disease and erectile dysfunction: a systematic review. American Journal of Men's Health 12 338-346. (https://doi.org/10.1177/1557988316639050)

Kellesarian SV, Malignaggi VR, Kellesarian TV, Al-Kheraif AA, Alwageet MM, Malmstrom H, Romanos GE \& Javed F 2017 Association between periodontal disease and polycystic ovary syndrome: a systematic review. International Journal of Impotence Research 29 89-95. (https://doi.org/10.1038/ijir.2017.7)

Kellesarian SV, Yunker M, Malmstrom H, Almas K, Romanos GE \& Javed F 2018b Male infertility and dental health status: a systematic review. American Journal of Men's Health 12 1976-1984. (https://doi. org/10.1177/1557988316655529)

Kern PA, Di Gregorio GB, Lu T, Rassouli N \& Ranganathan G 2003 Adiponectin expression from human adipose tissue: relation to obesity, insulin resistance, and tumor necrosis factor- $\alpha$ expression. Diabetes $\mathbf{5 2}$ 1779-1785. (https://doi.org/10.2337/diabetes.52.7.1779)

Khan S, Barrington G, Bettiol S, Barnett T \& Crocombe L 2018 Is overweight/obesity a risk factor for periodontitis in young adults and adolescents?: a systematic review. Obesity Reviews 19 852-883. (https:// doi.org/10.1111/obr.12668)

Kinane DF, Stathopoulou PG \& Papapanou PN 2017 Periodontal diseases. Nature Reviews: Disease Primers 3 17038. (https://doi.org/10.1038/ nrdp.2017.38)

Kjeldsen M, Holmstrup P \& Bendtzen K 1993 Marginal periodontitis and cytokines: a review of the literature. Journal of Periodontology $\mathbf{6 4}$ 1013-1022. (https://doi.org/10.1902/jop.1993.64.11.1013)

Klebanoff MA, Andrews WW, Yu KF, Brotman RM, Nansel TR, Zhang J, Cliver SP \& Schwebke JR 2006 A pilot study of vaginal flora changes with randomization to cessation of douching. Sexually Transmitted Diseases 33 610-613. (https://doi.org/10.1097/01. olq.0000216050.41305.c1)

Knebel B, Janssen OE, Hahn S, Jacob S, Gleich J, Kotzka J \& MullerWieland D 2008 Increased low grade inflammatory serum markers in patients with polycystic ovary syndrome (PCOS) and their relationship to PPAR $\gamma$ gene variants. Experimental and Clinical Endocrinology and Diabetes 116 481-486. (https://doi.org/10.1055/s-2008-1058085)

Koumans EH, Sternberg M, Bruce C, McQuillan G, Kendrick J, Sutton M \& Markowitz LE 2007 The prevalence of bacterial vaginosis in the United States, 2001-2004; associations with symptoms, sexual behaviors, and reproductive health. Sexually Transmitted Diseases 34 864-869. (https:// doi.org/10.1097/OLQ.0b013e318074e565)

Kshirsagar AV, Offenbacher S, Moss KL, Barros SP \& Beck JD 2007 Antibodies to periodontal organisms are associated with decreased kidney function: the dental atherosclerosis risk in communities study. Blood Purification 25 125-132. (https://doi.org/10.1159/000096411)

Kuczera P, Adamczak M \& Wiecek A 2015 Endocrine abnormalities in patients with chronic kidney disease. Prilozi 36 109-118. (https://doi. org/10.1515/prilozi-2015-0059)

Lalasa G, Murthy KRV, Pavankumar S \& Rama Raju GA 2014 Periodontal status in infertile women attending in vitro fertilization clinics. Indian Journal of Dental Research 25 50-53. (https://doi.org/10.4103/09709290.131055)

Lambertini L, Saul SR, Copperman AB, Hammerstad SS, Yi Z, Zhang W, Tomer Y \& Kase N 2017 Intrauterine reprogramming of the polycystic ovary syndrome: evidence from a pilot study of cord blood global methylation analysis. Frontiers in Endocrinology 8 352. (https://doi. org/10.3389/fendo.2017.00352)

Lang NP \& Bartold PM 2018 Periodontal health. Journal of Clinical Periodontology 45 (Supplement 1) 9-16.

Larsen JM 2017 The immune response to Prevotella bacteria in chronic inflammatory disease. Immunology 151 363-374. (https://doi. org/10.1111/imm.12760)

Lehti V, Brown AS, Gissler M, Rihko M, Suominen A \& Sourander A 2013 Autism spectrum disorders in IVF children: a national case-control study 
in Finland. Human Reproduction 28 812-818. (https://doi.org/10.1093/ humrep/des430)

Leridon H 1977 Human Fertility: The Basic Components. Chicago: University of Chicago Press.

Levey AS \& Coresh J 2012 Chronic kidney disease. Lancet 379 165-180. (https://doi.org/10.1016/S0140-6736(11)60178-5)

Li Y, Li R, Ouyang N, Dai K, Yuan P, Zheng L \& Wang W 2019 Investigating the impact of local inflammation on granulosa cells and follicular development in women with ovarian endometriosis. Fertility and Sterility 112 882-891.e1. (https://doi.org/10.1016/j.fertnstert.2019.07.007)

Machado V, Aguilera EM, Botelho J, Hussain SB, Leira Y, Proença L, D'Aiuto F \& Mendes JJ 2020a Association between periodontitis and high blood pressure: results from the study of periodontal health in Almada-Seixal (SoPHiAS). Journal of Clinical Medicine 9 1-13. (https:// doi.org/10.3390/jcm9051585)

Machado V, Botelho J, Lopes J, Patrão M, Alves R, Chambrone L, Alcoforado G \& Mendes JJ 2020b Periodontitis impact in interleukin-6 serum levels in solid organ transplanted patients: a systematic review and meta-analysis. Diagnostics 10 184. (https://doi.org/10.3390/ diagnostics10040184)

Macut D, Bjekić-Macut J, Rahelić D \& Doknić M 2017 Insulin and the polycystic ovary syndrome. Diabetes Research and Clinical Practice 130 163-170. (https://doi.org/10.1016/j.diabres.2017.06.011)

Maheshwari A, Hamilton M \& Bhattacharya S 2008 Effect of female age on the diagnostic categories of infertility. Human Reproduction $\mathbf{2 3}$ 538-542. (https://doi.org/10.1093/humrep/dem431)

Maiorino MI, Bellastella G, Giugliano D \& Esposito K 2018 From inflammation to sexual dysfunctions: a journey through diabetes, obesity, and metabolic syndrome. Journal of Endocrinological Investigation 41 1249-1258. (https://doi.org/10.1007/s40618-018-0872-6)

Mark Bartold PM \& Van Dyke TE 2013 Periodontitis: a host-mediated disruption of microbial homeostasis. Unlearning learned concepts. Periodontology 200062 203-217. (https://doi.org/10.1111/j.16000757.2012.00450.x)

Martinez-Herrera M, Silvestre-Rangil J \& Silvestre FJ 2017 Association between obesity and periodontal disease. A systematic review of epidemiological studies and controlled clinical trials. Medicina Oral, Patologia Oral Y Cirugia Bucal 22 e708-e715. (https://doi.org/10.4317/ medoral.21786)

Mascarenhas MN, Flaxman SR, Boerma T, Vanderpoel S \& Stevens GA 2012 National, regional, and global trends in infertility prevalence since 1990: a systematic analysis of 277 health surveys. PLoS Medicine 9 e1001356. (https://doi.org/10.1371/journal.pmed.1001356)

Matzuk MM \& Lamb DJ 2008 The biology of infertility: research advances and clinical challenges. Nature Medicine 14 1197-1213. (https://doi. org/10.1038/nm.f.1895)

McCartney CR \& Marshall JC 2016 Clinical practice. Polycystic ovary syndrome. New England Journal of Medicine 375 54-64. (https://doi. org/10.1056/NEJMcp1514916)

McDonald SD, Han Z, Mulla S, Ohlsson A, Beyene J, Murphy KE \& Knowledge Synthesis Group 2010 Preterm birth and low birth weight among in vitro fertilization twins: a systematic review and meta-analyses. European Journal of Obstetrics, Gynecology, and Reproductive Biology 148 105-113. (https://doi.org/10.1016/j.ejogrb.2009.09.019)

Meuleman C, Vandenabeele B, Fieuws S, Spiessens C, Timmerman D \& D'Hooghe T 2009 High prevalence of endometriosis in infertile women with normal ovulation and normospermic partners. Fertility and Sterility 92 68-74. (https://doi.org/10.1016/j.fertnstert.2008.04.056)

Meyle J \& Chapple I 2015 Molecular aspects of the pathogenesis of periodontitis. Periodontology 200069 7-17. (https://doi.org/10.1111/ prd.12104)

Mirza SS, Shafique K, Shaikh AR, Khan NA \& Anwar Qureshi M 2014 Association between circulating adiponectin levels and polycystic ovarian syndrome. Journal of Ovarian Research 7 18. (https://doi. org/10.1186/1757-2215-7-18)

Mitchell CM, Haick A, Nkwopara E, Garcia R, Rendi M, Agnew K, Fredricks DN \& Eschenbach D 2015 Colonization of the upper genital tract by vaginal bacterial species in nonpregnant women. American Journal of Obstetrics and Gynecology 212 611.e1-611.e9. (https://doi. org/10.1016/j.ajog.2014.11.043)

Morency AM, Shah PS, Seaward PGR, Whittle W \& Murphy KE 2016 Obstetrical and neonatal outcomes of triplet births-spontaneous versus assisted reproductive technology conception. Journal of Maternal-Fetal and Neonatal Medicine 29 938-943. (https://doi.org/10.3109/1476705 8.2015.1024649)

Moreno I, Codoñer FM, Vilella F, Valbuena D, Martinez-Blanch JF, Jimenez-Almazán J, Alonso R, Alamá P, Remohí J, Pellicer A et al. 2016 Evidence that the endometrial microbiota has an effect on implantation success or failure. American Journal of Obstetrics and Gynecology 215 684-703. (https://doi.org/10.1016/j.ajog.2016.09.075)

Moura-Grec PG, Marsicano JA, Carvalho CAP \& Sales-Peres SHde C 2014 Obesidade e periodontite: revisão sistemática e meta-análise. Ciencia e Saude Coletiva 19 1763-1772. (https://doi.org/10.1590/141381232014196.13482013)

Mullally BH, Coulter WA, Hutchinson JD \& Clarke HA 2007 Current oral contraceptive status and periodontitis in young adults. Journal of Periodontology 78 1031-1036. (https://doi.org/10.1902/ jop.2007.060163)

Murakami S, Mealey BL, Mariotti A \& Chapple ILC 2018 Dental plaque - induced gingival conditions. Journal of Clinical Periodontology 45 17-27. (https://doi.org/10.1002/JPER.17-0095)

Najah A, Salman SA, Akram H, Ahmed M, Wala L \& Khairi A 2017 Measurement of serum superoxide dismutase levels in women with polycystic ovarian syndrome and chronic periodontitis. Journal of Baghdad College of Dentistry 29 76-81.

National Kidney Foundation 2002 Clinical Practice Guidelines for Chronic Kidney Disease: Evaluation, Classification and Stratification.

Nibali L, Tatarakis N, Needleman I, Tu YK, D'Aiuto F, Rizzo M \& Donos N 2013 Clinical review: association between metabolic syndrome and periodontitis: a systematic review and meta-analysis. Journal of Clinical Endocrinology and Metabolism 98 913-920. (https://doi.org/10.1210/ jc.2012-3552)

Norman RJ, Dewailly D, Legro RS \& Hickey TE 2007 Polycystic ovary syndrome. Lancet $\mathbf{3 7 0}$ 685-697. (https://doi.org/10.1016/S01406736(07)61345-2)

Nwhator SO, Opeodu OI, Ayanbadejo PO, Umeizudike KA, Olamijulo JA, Alade GO, Agbelusi GA, Arowojolu MO \& Sorsa T 2014 Could Periodontitis affect time to conception? Annals of Medical and Health Sciences Research 4 817-822. (https://doi.org/10.4103/21419248.141567)

Omu FE \& Omu AE 2010 Emotional reaction to diagnosis of infertility in Kuwait and successful clients' perception of nurses' role during treatment. BMC Nursing 9 5. (https://doi.org/10.1186/14726955-9-5)

Onat G \& Beji NK 2012 Marital relationship and quality of life among couples with infertility. Sexuality and Disability 30 39-52. (https://doi. org/10.1007/s11195-011-9233-5)

Osibogun O, Ogunmoroti O \& Michos ED 2019 Polycystic ovary syndrome and cardiometabolic risk: opportunities for cardiovascular disease prevention. Trends in Cardiovascular Medicine 9-11. (https:// doi.org/10.1016/j.tcm.2019.08.010)

Özçaka Ö, Ceyhan BÖ, Akcali A, Biçakci N, Lappin DF \& Buduneli N 2012 Is there an interaction between polycystic ovary syndrome and gingival inflammation? Journal of Periodontology 83 1529-1537. (https://doi. org/10.1902/jop.2012.110588)

Özçaka Ö, Buduneli N, Ceyhan BO,Akcali A, Hannah V, Nile C \& Lappin DF 2013 Is interleukin-17 involved in the interaction between polycystic ovary syndrome and gingival inflammation? Journal of Periodontology 84 1827-1837. (https://doi.org/10.1902/jop.2013.120483)

Paju S, Oittinen J, Haapala H, Asikainen S, Paavonen J \& Pussinen PJ 2017 Porphyromonas gingivalis may interfere with conception in women. Journal of Oral Microbiology 9 1330644. (https://doi.org/10.1080/200 02297.2017.1330644)

Palmer BF \& Clegg DJ 2017 Gonadal dysfunction in chronic kidney disease. Reviews in Endocrine and Metabolic Disorders 18 117-130. (https://doi.org/10.1007/s11154-016-9385-9)

Pandey S, Shetty A, Hamilton M, Bhattacharya S \& Maheshwari A 2012 Obstetric and perinatal outcomes in singleton pregnancies resulting from ivf/icsi: a systematic review and meta-analysis. Human Reproduction Update 18 485-503. (https://doi.org/10.1093/humupd/dms018)

Parkar MH, Newman HN \& Olsen I 1996 Polymerase chain reaction analysis of oestrogen and androgen receptor expression in human gingival and periodontal tissue. Archives of Oral Biology 41 979-983. (https://doi.org/10.1016/s0003-9969(96)00053-2) 
Paschou SA, Polyzos SA, Anagnostis P, Goulis DG, Kanaka-Gantenbein C Lambrinoudaki I, Georgopoulos NA \& Vryonidou A 2020 Nonalcoholic fatty liver disease in women with polycystic ovary syndrome. Endocrine 67 1-8. (https://doi.org/10.1007/s12020-019-02085-7)

Pavela G, Kim YI \& Salvy SJ 2018 Additive effects of obesity and loneliness on C-reactive protein. PLoS ONE 13 e0206092. (https://doi.org/10.1371/ journal.pone.0206092)

Pavlatou A 2014 Periodontal disease, infertility treatment and in vitro fertilization (IVF). Journal of Fertilization 32.

Pawelczak M, Rosenthal J, Milla S, Liu YH \& Shah B 2014 Evaluation of the pro-inflammatory cytokine tumor necrosis factor- $\alpha$ in adolescents with polycystic ovary syndrome. Journal of Pediatric and Adolescent Gynecology 27 356-359. (https://doi.org/10.1016/j.jpag.2014.01.104)

Péloquin K, Brassard A, Delisle G \& Bédard M-M 2013 Integrating the attachment, caregiving, and sexual systems into the understanding of sexual satisfaction. Canadian Journal of Behavioural Science $\mathbf{4 5}$ 185-195. (https://doi.org/10.1037/a0033514)

Peres MA, Macpherson LMD, Weyant RJ, Daly B, Venturelli R, Mathur MR, Listl S, Celeste RK, Guarnizo-Herreño CC, Kearns C et al. 2019 Oral diseases: a global public health challenge. Lancet 394 249-260. (https:// doi.org/10.1016/S0140-6736(19)31146-8)

Petersen PE \& Ogawa H 2012 The global burden of periodontal disease: towards integration with chronic disease prevention and control. Periodontology $2000 \quad 60 \quad 15-39 . \quad$ (https://doi.org/10.1111/j.16000757.2011.00425.x)

Pinborg A, Wennerholm UB, Romundstad LB, Loft A, Aittomaki K, Söderström-Anttila V, Nygren KG, Hazekamp J \& Bergh C 2013 Why do singletons conceived after assisted reproduction technology have adverse perinatal outcome? Systematic review and meta-analysis. Human Reproduction Update 19 87-104. (https://doi.org/10.1093/ humupd/dms044)

Polak D \& Shapira L 2018 An update on the evidence for pathogenic mechanisms that may link periodontitis and diabetes. Journal of Clinical Periodontology 45 150-166. (https://doi.org/10.1111/jcpe.12803)

Porwal S, Tewari S, Sharma RK, Singhal SR \& Narula SC 2014 Periodontal status and high-sensitivity C-reactive protein levels in polycystic ovary syndrome with and without medical treatment. Journal of Periodontology 85 1380-1389. (https://doi.org/10.1902/jop.2014.130756)

Prachi S, Jitender S, Rahul C, Jitendra K, Priyanka M \& Disha S 2019 Impact of oral contraceptives on periodontal health. African Health Sciences 19 1795-1800. (https://doi.org/10.4314/ahs.v19i1.56)

Práger N, Pásztor N, Várnagy Á, Kozinszky Z, Baráth Z, Gorzó I \& Radnai M 2017 Idiopathic male infertility related to periodontal and caries status. Journal of Clinical Periodontology 44 872-880. (https://doi. org/10.1111/jcpe.12785)

Preshaw PM, Alba AL, Herrera D, Jepsen S, Konstantinidis A, Makrilakis K \& Taylor R 2012 Periodontitis and diabetes: a two-way relationship. Diabetologia 55 21-31. (https://doi.org/10.1007/s00125-011-2342-y)

Pretorius C, Jagatt A \& Lamont RF 2007 The relationship between periodontal disease, bacterial vaginosis, and preterm birth. Journal of Perinatal Medicine 35 93-99. (https://doi.org/10.1515/JPM.2007.039)

Puertas A, Magan-Fernandez A, Blanc V, Revelles L, O'Valle F, Pozo E, León R \& Mesa F 2017 Association of periodontitis with preterm birth and low birth weight: a comprehensive review. Journal of Maternal-Fetal and Neonatal Medicine 31 1-6.

Qin J, Sheng X, Wu D, Gao S, You Y, Yang T \& Wang H 2017 Adverse obstetric outcomes associated with in vitro fertilization in singleton pregnancies. Reproductive Sciences 24 595-608. (https://doi. org/10.1177/1933719116667229)

Rachoń D \& Teede H 2010 Ovarian function and obesity-interrelationship, impact on women's reproductive lifespan and treatment options. Molecular and Cellular Endocrinology 316 172-179. (https://doi. org/10.1016/j.mce.2009.09.026)

Rahiminejad ME, Moaddab A, Zaryoun H, Rabiee S, Moaddab A \& Khodadoustan A 2015 Comparison of prevalence of periodontal disease in women with polycystic ovary syndrome and healthy controls. Dental Research Journal 12 507-512. (https://doi.org/10.4103/17353327.170547)

Rajendran M, Priyadharshini V \& Arora G 2013 Is immunesenescence a contributing factor for periodontal diseases? Journal of Indian Society of Periodontology 17 169-174. (https://doi.org/10.4103/0972124X.113064)
Ralph SG, Rutherford AJ \& Wilson JD 1999 Influence of bacterial vaginosis on conception and miscarriage in the first trimester: cohort study. BMJ 319 220-223. (https://doi.org/10.1136/bmj.319.7204.220)

Ramezanzadeh F, Aghssa MM, Jafarabadi M \& Zayeri F 2006 Alterations of sexual desire and satisfaction in male partners of infertile couples. Fertility and Sterility 85 139-143. (https://doi.org/10.1016/j. fertnstert.2005.07.1285)

Ray A, Shah A, Gudi A \& Homburg R 2012 Unexplained infertility: an update and review of practice. Reproductive Biomedicine Online $\mathbf{2 4}$ 591-602. (https://doi.org/10.1016/j.rbmo.2012.02.021)

Ricardo AC, Athavale A, Chen J, Hampole H, Garside D, Marucha P \& Lash JP 2015 Periodontal disease, chronic kidney disease and mortality: results from the third national health and nutrition examination survey. BMC Nephrology 16 97. (https://doi.org/10.1186/s12882-015-0101-x)

Roberts FA \& Darveau RP 2015 Microbial protection and virulence in periodontal tissue as a function of polymicrobial communities: symbiosis and dysbiosis. Periodontology 200069 18-27. (https://doi.org/10.1111/ prd.12087)

Saglam E, Canakcı CF, Sebin SO, Saruhan N, Ingec M, Canakcı H \& Sezer U 2017 Evaluation of oxidative status in patients with chronic periodontitis and polycystic ovary syndrome: a cross-sectional study. Journal of Periodontology 89 1-16. (https://doi.org/10.1902/jop.2017.170129)

Schmidt L 2009 Social and psychological consequences of infertility and assisted reproduction - what are the research priorities? Human Fertility 12 14-20. (https://doi.org/10.1080/14647270802331487)

Schwebke JR, Morgan SC \& Weiss HL 1997 The use of sequential selfobtained vaginal smears for detecting changes in the vaginal flora. Sexually Transmitted Diseases 24 236-239. (https://doi.org/10.1097/00007435199704000-00009)

Scutiero G, Iannone P, Bernardi G, Bonaccorsi G, Spadaro S, Volta CA, Greco P \& Nappi L 2017 Oxidative stress and endometriosis: a systematic review of the literature. Oxidative Medicine and Cellular Longevity 2017 7265238. (https://doi.org/10.1155/2017/7265238)

Sharma P, Dietrich T, Ferro CJ, Cockwell P \& Chapple ILC 2016 Association between periodontitis and mortality in stages 3-5 chronic kidney disease: NHANES III and linked mortality study. Journal of Clinical Periodontology 43 104-113. (https://doi.org/10.1111/jcpe.12502)

Skarin A \& Sylwan J 1986 Vaginal lactobacilli inhibiting growth of Gardnerella vaginalis, Mobiluncus and other bacterial species cultured from vaginal content of women With bacterial vaginosis. Acta Pathologica Microbiologica Scandinavica Series B: Microbiology 94B 399-403.

Slopien R, Horst N, Jaremek JD, Chinniah D \& Spaczynski R 2019 The impact of surgical treatment of obesity on the female fertility. Gynecological Endocrinology 35 100-102. (https://doi.org/10.1080/09 513590.2018.1500536)

Smadi L 2017 Gingival and periodontal changes in patients undergoing in vitro fertilization treatment: a clinical study. Indian Journal of Dental Research 28 650-654. (https://doi.org/10.4103/ijdr.IJDR_712_16)

Spira A 1988 The decline of fecundity with age. Maturitas 10 (Supplement 1) 15-22. (https://doi.org/10.1016/0378-5122(88)90004-7)

Stadler AF, Angst PDM, Arce RM, Gomes SC, Oppermann RV \& Susin C 2016 Gingival crevicular fluid levels of cytokines/chemokines in chronic periodontitis: a meta-analysis. Journal of Clinical Periodontology 43 727-745. (https://doi.org/10.1111/jcpe.12557)

Stephenson J, Heslehurst N, Hall J, Schoenaker DAJM, Hutchinson J, Cade JE, Poston L, Barrett G, Crozier SR, Barker M et al. 2018 Before the beginning: nutrition and lifestyle in the preconception period and its importance for future health. Lancet 391 1830-1841. (https://doi. org/10.1016/S0140-6736(18)30311-8)

Stevens LA \& Levey AS 2009 Current status and future perspectives for CKD testing. American Journal of Kidney Diseases 53 (Supplement 3) S17-S26. (https://doi.org/10.1053/j.ajkd.2008.07.047)

Strömberg B, Dahlquist G, Ericson A, Finnström $O$, Köster $M$ \& Stjernqvist K 2002 Neurological sequelae in children born after in-vitro fertilisation: a population-based study. Lancet 359 461-465. (https://doi. org/10.1016/S0140-6736(02)07674-2)

Sudhakar M, Silambanan S, Chandran AS, Prabhakaran AA \& Ramakrishnan R 2018 C-reactive protein (CRP) and leptin receptor in obesity: binding of monomeric CRP to leptin receptor. Frontiers in Immunology 9 1167. (https://doi.org/10.3389/fimmu.2018.01167)

Sullivan-Pyke CS, Senapati S, Mainigi MA \& Barnhart KT 2017 In vitro fertilization and adverse obstetric and perinatal outcomes. 
Seminars in Perinatology 41 345-353. (https://doi.org/10.1053/j. semperi.2017.07.001)

Suresh S, Mahendra J, Kumar ARP, Singh G, Jayaraman S \& Paul R 2017 Comparative analysis of subgingival red complex bacteria in obese and normal weight subjects with and without chronic periodontitis. Journal of Indian Society of Periodontology 21 186-191. (https://doi. org/10.4103/jisp.jisp_241_17)

Suvan J, D'Aiuto F, Moles DR, Petrie A \& Donos N 2011 Association between overweight/obesity and periodontitis in adults. A systematic review. Obesity Reviews 12 e381-e404. (https://doi.org/10.1111/j.1467789X.2010.00808.x)

Swidsinski A, Verstraelen H, Loening-Baucke V, Swidsinski S, Mendling W \& Halwani Z 2013 Presence of a polymicrobial endometrial biofilm in patients with bacterial vaginosis. PLOS ONE 8 e53997. (https://doi. org/10.1371/journal.pone.0053997)

Te Velde E, Burdorf A, Nieschlag E, Eijkemans R, Kremer JAM, Roeleveld N \& Habbema D 2010 Is human fecundity declining in Western countries? Human Reproduction 25 1348-1353. (https://doi.org/10.1093/humrep/ deq085)

Thomas V, Uppoor AS, Pralhad S, Naik DG \& Kushtagi P 2018 Towards a common etiopathogenesis: periodontal disease and endometriosis. Journal of Human Reproductive Sciences 11 269-273. (https://doi. org/10.4103/jhrs.JHRS_8_18)

Tilakaratne A, Soory M, Ranasinghe AW, Corea SMX, Ekanayake SL \& De Silva M 2000 Effects of hormonal contraceptives on the periodontium, in a population of rural Sri-Lankan women. Journal of Clinical Periodontology 27 753-757. (https://doi.org/10.1034/j.1600-051x.2000.027010753.x)

Tonetti MS, Van Dyke TE \& Working Group 1 of the Joint EFP/AAP Workshop 2013 Periodontitis and atherosclerotic cardiovascular disease: consensus report of the joint EFP/AAP workshop on periodontitis and systemic diseases. Journal of Periodontology 84 (Supplement) S24-S29. (https://doi.org/10.1902/jop.2013.1340019)

Tonetti MS, Eickholz P, Loos BG, Papapanou P, Van Der Velden U, Armitage G, Bouchard P, Deinzer R, Dietrich T, Hughes F et al. 2015 Principles in prevention of periodontal diseases: consensus report of group 1 of the 11th European workshop on periodontology on effective prevention of periodontal and peri-implant diseases. Journal of Clinical Periodontology 42 (Supplement 16) S5-S11. (https://doi.org/10.1111/ jcpe.12368)

Tonetti MS, Greenwell H \& Kornman KS 2018 Staging and grading of periodontitis : framework and proposal of a new classification and case definition. Journal of Clinical Periodontology 45(Supplement 20) S149_ S161. (https://doi.org/10.1111/jcpe.12945)

Tong C, Wang YH, Yu HC \& Chang YC 2019 Increased risk of polycystic ovary syndrome in Taiwanese women with chronic periodontitis: a nationwide population-based retrospective cohort study. Journal of Women's Health 28 1436-1441. (https://doi.org/10.1089/jwh.2018.7648)

Trombelli L, Farina R, Silva CO \& Tatakis DN 2018 Plaque-induced gingivitis: case definition and diagnostic considerations. Journal of Periodontology 89 (Supplement 1) S46-S73. (https://doi.org/10.1002/ JPER.17-0576)

Vallvé-Juanico J, Santamaria X, Vo KC, Houshdaran S \& Giudice LC 2019 Macrophages display proinflammatory phenotypes in the eutopic endometrium of women with endometriosis with relevance to an infectious etiology of the disease. Fertility and Sterility 112 1118-1128. (https://doi.org/10.1016/j.fertnstert.2019.08.060)

van der Velden U 1984 Effect of age on the periodontium. Journal of Clinical Periodontology 11 281-294. (https://doi.org/10.1111/j.1600051x.1984.tb01325.x)

Van Langendonckt A, Casanas-Roux F \& Donnez J 2002 Oxidative stress and peritoneal endometriosis. Fertility and Sterility 77 861-870. (https:// doi.org/10.1016/s0015-0282(02)02959-x)

van Oostrum N, De Sutter P, Meys J \& Verstraelen H 2013 Risks associated with bacterial vaginosis in infertility patients: a systematic review and meta-analysis. Human Reproduction 28 1809-1815. (https://doi. org/10.1093/humrep/det096)
Vander Borght M \& Wyns C 2018 Fertility and infertility: definition and epidemiology. Clinical Biochemistry 62 2-10. (https://doi.org/10.1016/j. clinbiochem.2018.03.012)

Vassalotti JA, Stevens LA \& Levey AS 2007 Testing for chronic kidney disease: a position statement from the National Kidney Foundation. American Journal of Kidney Diseases 50 169-180. (https://doi. org/10.1053/j.ajkd.2007.06.013)

Vasudevan S, Renuka JV, Sylvia DS, Challa R, Padmakanth M \& Reddy A 2013 Evaluation of gingival inflammation in patients using ovulation induction drugs before and after scaling. Journal of Contemporary Dental Practice 14 1165-1168. (https://doi.org/10.5005/jp-journals-10024-1469)

Vercellini P, Viganò P, Somigliana E \& Fedele L 2014 Endometriosis: pathogenesis and treatment. Nature Reviews: Endocrinology 10 261-275. (https://doi.org/10.1038/nrendo.2013.255)

Vermeiden JPW \& Bernardus RE 2013 Are imprinting disorders more prevalent after human in vitro fertilization or intracytoplasmic sperm injection? Fertility and Sterility 99 642-651. (https://doi.org/10.1016/j. fertnstert.2013.01.125)

Victor VM, Rovira-Llopis S, Bañuls C, Diaz-Morales N, De Marañon AM, Rios-Navarro C, Alvarez A, Gomez M, Rocha M \& Hernández-Mijares A 2016 Insulin resistance in PCOS patients enhances oxidative stress and leukocyte adhesion: role of myeloperoxidase. PLOS ONE 11 1-16.

Visioli F \& Hagen TM 2011 Antioxidants to enhance fertility: role of eNOS and potential benefits. Pharmacological Research 64 431-437. (https:// doi.org/10.1016/j.phrs.2011.06.021)

Webster AC, Nagler EV, Morton RL \& Masson P 2017 Chronic kidney disease. Lancet 389 1238-1252. (https://doi.org/10.1016/S0140-6736(16)32064-5)

Wilson JD, Ralph SG \& Rutherford AJ 2002 Rates of bacterial vaginosis in women undergoing in vitro fertilisation for different types of infertility. BJOG 109 714-717. (https://doi.org/10.1111/j.14710528.2002.01297.x)

Wisborg K, Ingerslev HJ \& Henriksen TB 2010 IVF and stillbirth: a prospective follow-up study. Human Reproduction 25 1312-1316. (https://doi.org/10.1093/humrep/deq023)

Wood JW 1989 Fecundity and natural fertility in humans. Oxford Reviews of Reproductive Biology 11 61-109.

Wu M, Chen SW \& Jiang SY 2015 Relationship between gingival inflammation and pregnancy. Mediators of Inflammation 2015623427. (https://doi.org/10.1155/2015/623427)

Yamamoto T, Zhou X, Williams CJ, Hochwalt A \& Forney LJ 2009 Bacterial populations in the vaginas of healthy adolescent women. Journal of Pediatric and Adolescent Gynecology 22 11-18. (https://doi. org/10.1016/j.jpag.2008.01.073)

Yudin MH 2005 Bacterial vaginosis in pregnancy: diagnosis, screening, and management. Clinics in Perinatology 32 617-627. (https://doi. org/10.1016/j.clp.2005.05.007)

Zegers-Hochschild F, Adamson GD, Dyer S, Racowsky C, De Mouzon J, Sokol R, Rienzi L, Sunde A, Schmidt L, Cooke ID et al. 2017 The international glossary on infertility and fertility care, 2017. Human Reproduction 32 1786-1801. (https://doi.org/10.1093/humrep/dex234)

Zhu C, Qin Z, Huang H, Li X \& Feng Y 2010 The correlation study between male infertility and chronic periodontitis. Modern Medicine 298.

Zhu JL, Basso O, Obel C, Bille C \& Olsen J 2006 Infertility, infertility treatment, and congenital malformations: Danish national birth cohort. BMJ 333 679. (https://doi.org/10.1136/bmj.38919.495718.AE)

Zollner U \& Dietl J 2013 Perinatal risks after IVF and ICSI. Journal of Perinatal Medicine 41 17-22. (https://doi.org/10.1515/jpm-2012-0097)

Received 27 March 2020

First decision 12 May 2020

Revised manuscript received 10 June 2020

Accepted 23 June 2020 